\title{
The Notch pathway in the developing hematopoietic system
}

\author{
ANNA BIGAS*,1, ÀLEX ROBERT-MORENO ${ }^{2}$ and LLUÍS ESPINOSA ${ }^{1}$ \\ ${ }^{1}$ Program in Cancer Research. IMIM-Hospital del Mar and \\ ${ }^{2}$ Departament de Ciències Experimentals. Universitat Pompeu Fabra, Barcelona, Spain
}

\begin{abstract}
The main function of the Notch signaling pathway is to generate cell diversity during both embryonic development and adult tissue homeostasis. The extended use of this pathway, together with its conservation during evolution, is indicative of its importance. During embryonic development, the vascular and hematopoietic systems are intimately associated and Notch signals are responsible for the correct specification of both systems. More explicitly, Notch is required for the induction of the arterial program; however, it is simultaneously or consecutively also involved in the generation of hematopoietic stem cells. Although both genetic programs are different, they are both implemented in endothelial cells of the dorsal aorta in the midgestation embryo. This close association during the development of arteries and blood has hindered our understanding of Notch function in the generation of hematopoietic stem cells. Here, we will review the work from recent years showing how Notch participates in the embryonic development of hematopoiesis in the mouse, but also in other organisms such as chick, zebrafish and flies.
\end{abstract}

KEY WORDS: Notch, AGM, yolk sac, hematopoiesis, embryo

\section{The Notch pathway and cell fate specification}

During evolution, multicellular organisms have developed regulatory mechanisms to ensure the fine-tuned and reproducible development of the different organs and tissues. Direct cell-cell interactions between neighbouring cells are crucial to govern most of these processes and one of the important pathways regulating these interactions is the Notch pathway [reviewed in (Lai 2004)].

Notch was first identified in 1914 by genetic experiments in Drosophila and received its name from indentations (notches) that form in the wing of mutant flies (Dexter 1914) (Morgan TH,CB 1916). Since then, Notch function has been the focus of extensive research and nowadays it is known that it regulates a wide variety of developmental processes such as neurogenesis, miogenesis, hematopoiesis, intestinal and pancreatic differentiation, wing formation and somite segregation among others (reviewed in Lewis, 1998). In this review, we will present an extensive overview of the role of Notch signaling pathway in vascular and hematopoietic development.

\section{Key players and mechanisms}

The Notch signaling pathway includes Notch receptors, the Delta and Serrate/Jagged ligands and the nuclear transcription factor CSL (that accounts for CBF1; recombinant binding proteinJ kappa (RBPjк); Suppressor of Hairless (Su[H]); Lag-1). Indicative of the importance of this pathway, orthologues of most Notch family members are found during evolution from nematodes to mammals as summarized in Table 1.

\section{The Notch receptor}

The Notch receptor is a transmembrane protein involved in transducing specific extracellular signals to the nucleus in response to ligand binding. The extracellular part of the receptor contains multiple epidermal growth factor (EGF) repeats. In flies, repeats 11 and 12 of the Notch receptor are responsible for ligand-binding (Rebay et al., 1991). The extracellular part of the receptor also contains the Lin/Notch repeats (LNR), involved in maintaining the heterodimeric structure by disulphide bridges, thus preventing ligand-independent activation (Weng etal., 2004). The intracellular Notch (NotchIC) contains several functional domains including the RAM domain and the ankyrin (ANK) repeats, required for the interaction with its intracellular partners; the nuclear localization signals; the transactivation domain and

Abbreviations used in this paper: AGM, aorta-gonad-mesonephros; HSC, hematopoietic stem cell; KSL, c-kit ${ }^{+} \mathrm{Scal}^{+} \mathrm{Lin}^{-}$; P-Sp, para-aortic splanchnopleura; YS, yolk sac.

\footnotetext{
*Address correspondence to: Anna Bigas. IMIM-Hospital del Mar, Parc de Recerca Biomèdica de Barcelona, PRBB, Dr. Aiguader 88, 08903, Barcelona, Spain. Fax: +34-93-316-0410. e-mail: abigas@imim.es
} 
the C-terminal PEST domain that regulates protein stability (Fryer et al., 2002; Thompson et al., 2007). Notch molecule is translated from a single mRNA transcript, that in the Golgi complex is first cleaved ( $\mathrm{S} 1$ site) by a furin convertase and subsequently reassembled by disulphite bridges into the functional heterodimeric receptor present at the cell surface [reviewed in (Maillard et al., 2003)] (see Fig. 1).

\section{Jagged and Delta ligands}

Signaling through the Notch receptor is triggered by the interaction with one of the Notch ligands expressed in the adjacent cell (presenting cell) (see Fig. 1). The Notch ligands are transmembrane proteins that contain multiple EGF-like repeats and a characteristic DSL domain (DSL accounts for Delta, Serrate and Lag2). Both EGF and DSL repeats are involved in Notch receptor interaction, however peptides solely containing the DSL domain are sufficient to activate Notch in some systems (Shimizu et al., 2000). Two different ligands have been identified in Drosophila (Delta and Serrate), whereas five different ligands are present in vertebrates (Jagged1,2, Delta1,3,4), and an additional ligand, Delta2, specific for Xenopus. Serrate and its orthologues Jagged1 and 2 differ from Delta ligands in the number of EGF-like repeats and in the presence of a cysteine-rich domain [reviewed in (Ohishi et al., 2003)]. The intracellular domain of Jagged and Delta is composed by a few aminoacids and it is not known whether it displays any function in the presenting cell.

Glycosilation of the Notch receptor by Fringe glycosyltransferases (Radical, Lunatic and Manic Fringe) is responsible for modulating ligand specificity. Fringe proteins can regulate Notch activity and contribute to the generation of cell diversity [reviewed in (Irvine 1999)].

The importance of ubiquitination is evidenced by the Notch-

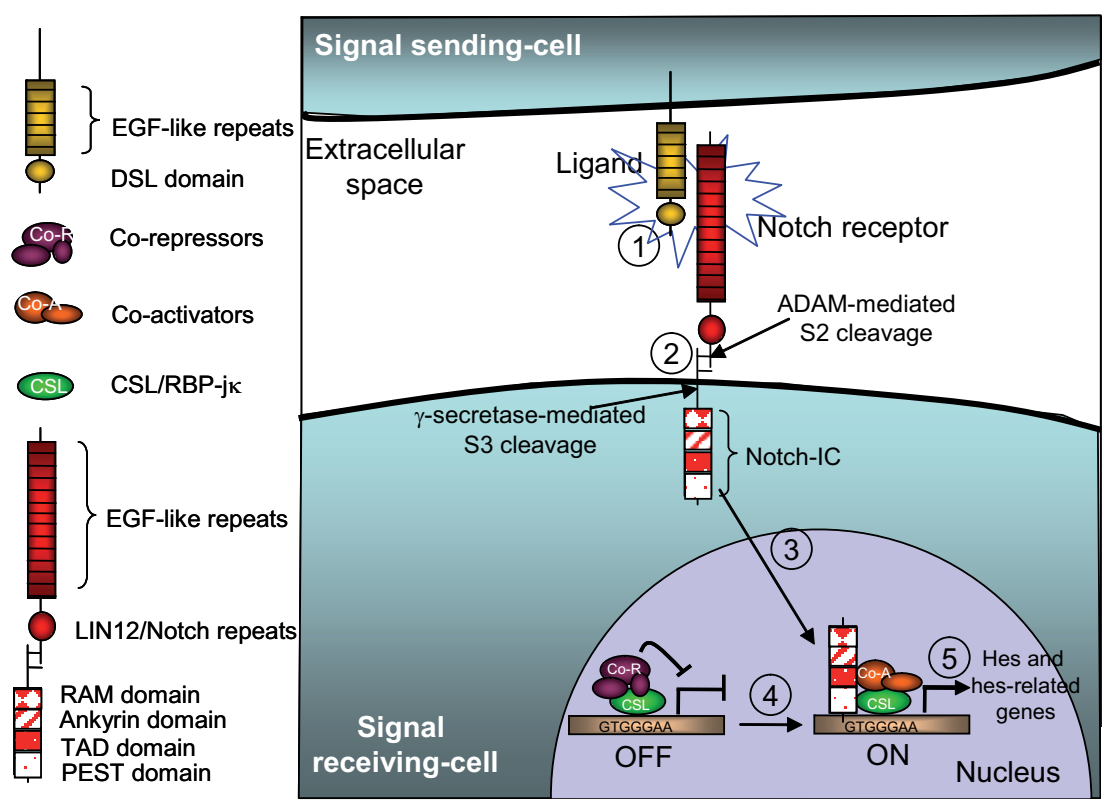

Fig. 1. Sequence of events in the canonical Notch signal. Interaction between ligand and receptor (1) leads to a cascade of proteolytic events: one extracellular (ADAMmetalloproteases) and one intracellular ( $\gamma$-secretase) (2), resulting in Notch/C translocation to the nucleus (3), exchange of a repressor complex by an activator complex (4) and Notch/C/RBPjK dependent target gene expression such as hes and hes-related genes (5).
TABLE 1

\section{BASIC COMPONENTS OF THE NOTCH SIGNALING PATHWAY}

\begin{tabular}{llll} 
Notch pathway element & C. elegans & D. melanogaster & Mammals \\
\hline Receptor (Notch) & LIN-12 & Notch & Notch1 \\
& GLP-1 & & Notch2 \\
& & & Notch3 \\
& & & Notch4 \\
Ligand & LAG-2 & Delta & Delta1/Delta-like1 (DII1) \\
& APX-1 & Serrate & Delta3/Delta-like3 (DIII) \\
& ARG-2 & & Delta4/Delta-like4 (DII4) \\
& F26B12.2 & & Jagged1 (JAG1) \\
& & & Jagged2 (JAG2) \\
DNA-binding protein (CSL) & LAG-1 & Suppressor of Hairless & CBF1/RBPjk \\
& & $($ Su(H)) & RBPL \\
\hline
\end{tabular}

Adapted from Lai (2004). Notch receptor, ligand and transcription factor in different species (Caenhorabditis elegans, Drosophila melanogaster and mammals).

loss of function phenotypes produced by mutations in the Deltaspecific E3 ubiquitin ligases Neuralizedand Mind bomb(Lai et al., 2001; Itoh et al., 2003). Recent studies have shown that ubiquitination regulates endocytosis of the Delta ligand that is required for Notch activation [reviewed in (Ben-Yaacov et al., 2001)].

\section{Activation of the Notch pathway}

The unbalanced levels of Notch receptors and ligands on the surface of adjacent cells trigger the activation of the Notch pathway (see Fig. 1). Binding of the Notch receptor to one of its ligands leads to two successive proteolytic cleavages in the Notch molecule (Kopan et al., 1996) which in turn, is translocated to the nucleus to exert its function. The first cleavage (S2) occurs in the extracellular domain at the LIN/Notch repeats (LNR) and it is mediated by an ADAM metalloprotease called TACE (TNF- $\alpha$ converting enzyme) in vertebrates or Kuzbanianin Drosophila. It has recently been demonstrated that endocytosis of the Delta ligand bound to extracellular domain of Notch facilitates the S2 cleavage (Nichols et al., 2007). Following this first cleavage, Notch receptor suffers a conformational change that converts the receptor into a substrate for a multiprotein complex formed by presenilin, nicastrin, Aph1 and Pen-2 that displays $\gamma$-secretase activity. This complex cleaves Notch within the transmembrane domain thus leading to the release of its intracellular fragment (Notchintra or NotchIC) that is the active form of the receptor [reviewed in (Lai 2004)]. Blocking $\gamma$ secretase activity with pharmacological inhibitors or by genetic inactivation of members of the $\gamma$-secretase complex prevents Notch signaling (Zhang et al., 2000).

After cleavage, NotchIC translocates to the nucleus where it associates with its downstream effector, the transcription factor CSL. In the absence of Notch activation, CSL is bound to specific binding sites in the DNA (C/T)GTGGGAA) and represses specific gene transcription by recruiting corepressors (NcoRs) and histone deacetylases (HDACs) (Kao et al., 1998). Binding of NotchIC to CSL displaces transcriptional repressors and recruits coactivators, such as 
p300, or the 'specific' Notch coactivator Mastermind, leading to gene activation (see Fig. 1). The best-characterized Notch target genes are the Hairy and Enhancer of Split (hes) and hes-related (hrt) family of transcription factors. There are seven hes genes (hes1-7) in mammals, based on sequence homology, but only hes1 (Jarriault et al., 1995), hes5 (Ohtsuka et al., 1999) and hes7 (Hirata et al., 2000) as well as hrt1/herp2 and hrt2/herp1 are activated by Notch [reviewed in (Iso et al., 2003)]. Hes and Hrt proteins are basic helix-loop-helix (bHLH) factors that generally function as transcriptional repressors in association with Groucho/ TLE by binding to N-box sequences (CACNAG). In general, Hes and Hrt proteins mediate most of the Notch effects on cell differentiation in several systems including inhibition of neurogenesis, myogenesis, hematopoiesis or intestinal differentiation [reviewed in (Ohishi et al., 2003)].

\section{Control of cell-fate decisions}

During development but also during adult life, complex systems formed by cells with different functional qualities are generated from pluripotent cells with equivalent developmental potential. In most of them, the interactions between Notch and Jagged/ Delta are responsible for inducing cellular diversity from common progenitors through the activation of specific genetic programs [reviewed in (Lewis 1998)]. Two different mechanisms have been proposed to explain how Notch regulates cell diversity: lateral inhibition and lateral induction.

\section{Lateral inhibition model}

In the lateral inhibition model, a hypothetical initial population of equivalent cells that express similar levels of both Notch receptor and ligand. By stochastic events, one cell upregulates the expression of the ligand, which will be responsible to activate Notch receptor in the neighbouring cells. This leads to the subsequent downregulation of the ligand by negative feedback loops, allowing the maintenance and intensification of the differences in expression of receptors and ligands generating a "salt-and-pepper" mosaic of cells. As a result Notch is specifically activated in the receptor-expressing cells to inhibit differentiation whereas ligand-expressing cells differentiate (see model in Fig. 2A) [reviewed in (Lewis 1998)]. The neural-epidermal choice in Drosophila is the paradigm of the lateral inhibition model. Specification of the neural lineage requires the expression of the achaete-scute bHLH transcription factors that are repressed by Notch activation through the Enhancer of split Complex [E(spl)-C]. Thus, Notch activation results in the inhibition of the neural fate permitting the epidermal differentiation (Parks et al., 1997). In mammals, this mechanism is conserved and controls neurogenesis, intestinal differentiation and myogenesis through the repression of Math1, Mash1 and $M y o D$ by the ortholog of Hairy/E(spl)-related bHLH repressors, Hes [reviewed in (ArtavanisTsakonas et al., 1999)].

\section{Lateral induction model}

Some Notch effects also fit with a lateral induction model. In this case, a given cell type that expresses Notch ligands induces Notch activity in a different compartment of adjacent cells that will differentiate and diverge from the initial population. In this case, expression of active Notch induces rather than inhibits differentiation (see Fig. 2B) [reviewed in (Lewis 1998)]. In Droso phila, one example of lateral induction is the delimitation of the wing margin through Notch-mediated activation of the transcriptional coactivator vestigia/in the wing imaginal disc (Couso et al., 1995). In vertebrates a classical example is somite formation. Somites are regularly spaced blocks of mesoderm that split off from the presomitic mesoderm in a periodic oscillatory manner. Somite boundaries are generated by a Notch-dependent transcriptional activation of hes and lunatic fringe followed by a negative feedback of Lunatic fringe on Notch activity (Dale et al., 2003). Although these two models are useful to explain some of the Notch effects, other developmental events are likely to be more complex.

\section{The ontogeny of the hematopoietic system}

The hematopoietic system has evolved to ensure nutrient supply and protection from external challenges in multicellular organisms. The blood is composed of a large variety of mature cell types with a limited life-span (i.e two days for neutrophils, thirty days for erythrocytes), that need to be constantly replenished from a pool of hematopoietic stem cells (HSCs). This process is known as hematopoiesis [reviewed in (Godin and Cumano 2002)].

During embryonic development, the major site of hematopoiesis shifts from one organ to another in a dynamic temporal and
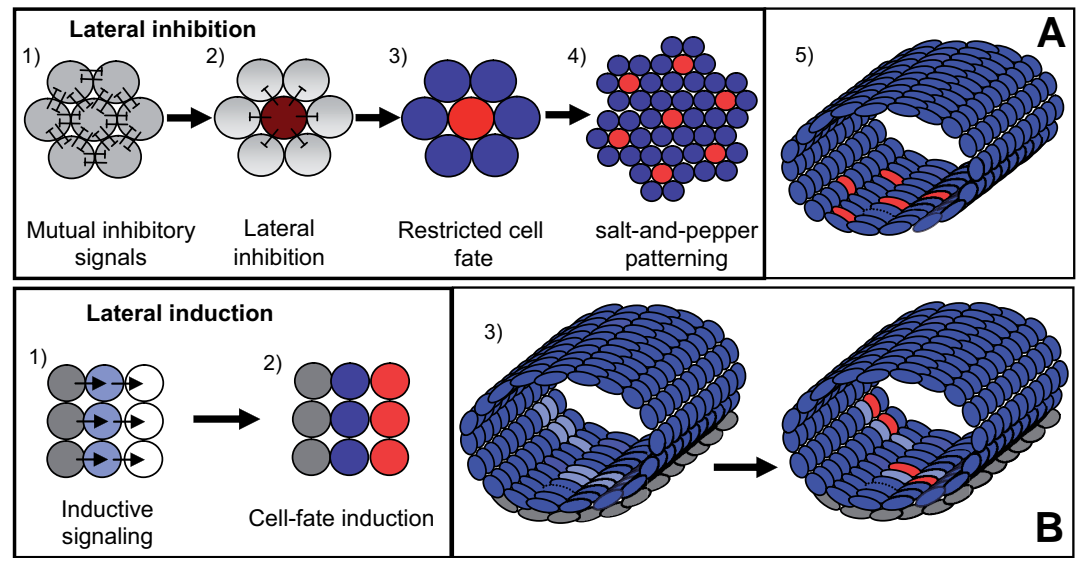

Fig. 2. Lateral inhibition (A) and induction (B) models. (A) The lateral inhibition model: (1) Equivalent cells expressing receptor and ligand exert mutual inhibitory signals. (2) One of these cells expresses high levels of ligand, inhibiting the expression in the surrounding cells. (3) The ligand expressing cell switches on a different genetic program than the neighbouring cells and adopts a different cellular fate (hematopoietic in red). (4) As a result, a salt-and-pepper pattern is generated that (5) in the aorta could induce the formation of hematopoietic cells while preserving endothelial integrity. (B) Lateral induction model. (1) A group of cells (mesenchyme in grey) signal to the adjacent blue cells (hemogenic endothelium/hemangioblast in light blue). (2) Subsequently, these cells induce a new fate in the neighbouring cells expressing Notch (hematopoietic cells in red) whereas the rest of cells remain endothelium with hemogenic capacity. (3) In the aorta, few hemangioblastic cells may have the capacity to become hematopoietic by restricting the endothelial fate through lateral inhibition signals and a combination of both models may be operating. (Notch models are inspired in Artavanis-Tsakonas et al., (Artavanis Tsakonas et al., 1995)). 
spatial manner (reviewed in this number). In the extra-embryonic yolk sac, at E7 in the mouse, the mesoderm layer develops into structures referred as blood islands, responsible for the first wave of hematopoiesis also known as primitive hematopoiesis (Silver and Palis 1997). This process mainly generates nucleated erythrocytes that are characterized by the expression of embryonic hemoglobins ( $\varepsilon$ and $\beta \mathrm{H} 1$ ). During the $6-8$ somite pair stages (E88.5), the mouse embryo suffers the process of "turning" or axial rotation, in which achieves the characteristic "fetal" position ((Kaufman 1994)), and shortly after, circulation between the embryo and the yolk sac through the vitelline vessels starts. Beginning E9, the intra-embryonic para-aortic splanchnopleura (P-Sp) mesoderm gives rise to the fused aorta surrounded by gonads and mesonephros, a region referred as AGM. The definitive/adult HSCs (defined as those cells able to self-renew and repopulate the whole hematopoietic system when transplanted into adult irradiated mice) are first detected in the AGM region as early as E9 (Godin et al., 1995; Medvinsky and Dzierzak 1996). However, at E8.5 and before circulation between the yolk sac and the embryo is stablished, intraembryonic mesodermal-derived regions are able to generate hematopoietic cells under specific experimental conditions (Cumano et al., 1996). The HSCs and other progenitors mainly develop from the ventral part of the dorsal aorta in the AGM (Garcia-Porrero et al., 1995) but also from other major vessels such as the umbilical and vitelline arteries (de Bruijn et al., 2000). Original studies by Dièterlen-Lièvre using chick and quail chimeras demonstrated that, at least in this system, hematopoiesis comes entirely from the embryo proper (Lassila et al., 1978), however, evidence has also been collected that supports the origin of hematopoietic cells in the yolk sac (Yoder and Hiatt 1997; Yoder et al., 1997; Yoder et al., 1997), the placenta (Muller et al., 1994; Medvinsky and Dzierzak 1996; Kumaravelu et al., 2002; Gekas et al., 2005; Ottersbach,Dzierzak 2005), the allantois (Zeigler et al., 2006; Corbel et al., 2007) and the subaortic patches (mesenchyme under the floor of the dorsal aorta) (Manaia et al., 2000; Bertrand et al., 2005). Although some controversy still exists, cell tracing experiments have recently demonstrated that HSC are originated from a VE-cadherin expressing cell population present in midgestation embryos (Zovein et al., 2008; Chen et al., 2009). Recently, life imaging technology has provided new evidence that further supports the emergence of hematopoietic stem cells from the endothelial cells in zebrafish and mouse embryos (Boisset et al., 2010, Kissa and Herbomel, 2010, Lam et al., 2010).

Around E11, fetal liver becomes active as hematopoietic site with HSC activity. However, since HSCs appear in the embryo before fetal liver is formed, this activity may necessarily be originated in other hematopoietic niches and next colonize the liver for further differentiation and expansion. Consistent with this, stem cell activity is detected in embryonic circulating blood just before it is found in fetal liver. Colonization of both the fetal thymus (where T-cell differentiation occurs) and the spleen (responsible for B-cell generation) by HSCs starts around E12 (Godin et al., 1999). Near the end of gestation (E15-16), the presence of HSC in fetal liver and spleen regresses concomitant with the migration of these cells to the bone marrow that will the principal hematopoietic organ through adult life (Metcalf et al., 1971). However, spleen and thymus will remain adult hematopoietic organs, responsible for the final maturation of $B$ and $T$ cells respectively, together with the lymph nodes.

The ontogeny of the human and mouse hematopoietic systems are comparable. The first blood islands appear in the human embryo around day 18 of gestation, and YS primitive erythropoiesis takes place from weeks 3-6. HSCs generation in the AGM occurs at weeks 5-7. From weeks 6-22, fetal liver acts as the major hematopoietic site and finally the bone marrow becomes the lifelong site of blood-cell production [reviewed in (Palis, Yoder 2001)].

\section{Direct relationship between hematopoietic and endothe- lial lineages}

In 1917, Florence R. Sabin showed that hematopoietic cells in the blood islands of the yolk sac developed closely in time and space to endothelial cells [re-published in (Sabin 2002). This observation raised the possibility that a common mesodermal progenitor for both lineages, the hemangioblast, exists. This could also be the case in the AGM region where hematopoietic clusters emerge from the ventral part of the dorsal aorta within, or in close association with, the endothelial cell layer (Garcia-Porrero et al., 1995; de Bruijn et al., 2000; de Bruijn et al., 2002). In the mouse, hematopoietic clusters contain HSCs that express CD34, CD45 and c-Kit (Tavian et al., 1996; North etal., 1999; North et al., 2002) markers. Comparable structures have been described in bird, zebrafish, amphibian and human embryos (Tavian et al., 1996; Thompson et al., 1998; North et al., 1999). Cells within aortic/AGM clusters also express transcription factors required for definitive hematopoiesis such as Runx1, c-Myb, Gata2 and Scl (North et al., 1999; de Bruijn etal., 2002; Bertrand et al., 2005; Robert-Moreno et al., 2005).

Recent work using transgenic mice that express the green fluorescent protein (GFP) under the control of Ly-6A/Sca-1 promoter, a well characterized HSC marker, has revealed the presence of a Sca-1-expressing cell population that resides in the endothelial layer of the dorsal aorta in the AGM region and express the endothelial marker CD31. This population displays long-term repopulating activity, strongly suggesting a common endothelial-hematopoietic origin of HSCs in the AGM (de Bruijn et al., 2002). Multiple experimental evidences support the existence of this common precursor. For example, endothelial cells, characterized by the presence of exclusive endothelial markers, are able to generate hematopoietic cells in vitro (Eichmann et al., 1997). Moreover, murine embryoid bodies contain blast-colony forming cells that can differentiate into endothelial or hematopoietic cells upon secondary replating (Cho,Choi 1998). Finally, Wang's group identified an endothelial-like subpopulation (PECAM-1, VE-cadherin, Flk-1 positive) within human ES cells with hemangioblastic properties (Wang et al., 2004).

In agreement with their possible common origin, hematopoietic and endothelial cells share a great number of cell surface markers: PECAM-1/CD31 (platelet endothelial cell adhesion molecule-1), angiopoietin receptor Tie-2, CD34, VE-cadherin and the VEGF receptor-2, Flk-1 (Young et al., 1995; Hamaguchi et al., 1999; North et al., 1999; Hsu et al., 2000; Huber et al., 2004). In addition, several targeted mutations in endothelial genes strongly compromise the hematopoietic development in mice. For example, mice deficient for Flk-1 (Shalaby et al., 1995) or the transcription factor Scl (Robb et al., 1995) die at 
early stages of development due to severe hematopoietic and endothelial disorders. However, since endothelial development is a prerequisite for hematopoiesis to occur it is difficult to establish whether these mutations affect hematopoiesis per se or this is a side effect of endothelial failure. In fact, Flk-1deficient ES cells failed to contribute not only to the vascular endothelium but also to primitive and definitive hematopoiesis in mouse chimeras (Shalaby et al., 1997), but these results cannot distinguish between both possibilities. More recently, a cell population that expresses the brachyurymesodermal marker and Flk-1, first detected in the primitive streak of the mouse embryo, was shown to be the precursor of both endothelial and hematopoietic cells of the yolk sac (Huber et al., 2004).

Further supporting the idea that endothelial and hematopoietic cells come from a common progenitor, chimeras of quail splanchnopleural mesoderm into chicken embryos revealed that HSCs in the AGM come from mesodermal cells that migrate and integrate into the floor of the aorta to generate hematopoietic clusters (Dieterlen-Lievre et al., 1997).

\section{The arterial program precedes hematopoiesis}

Blood vessels are formed during embryonic development by two different processes known as vasculogenesis and angiogenesis. The former comprises the differentiation and assembly of mesoderm-derived endothelial cells into a network of primitive blood vessels homogeneous in size, while the latter involves the morphological changes of this vascular plexus required to generate the mature vascular system. A great number of signaling pathways have been implicated in the control of both processes, including the vascular endothelial growth factor (VEGF) or the Angiopoietin/Tie receptor and, more recently, the Notch signaling pathway.

Lineage tracing experiments in the zebrafish embryo provided evidence that endothelial precursor cells are specified in the lateral posterior mesoderm to form either the artery or the vein but never both (Zhong et al., 2001). Notch-regulated gene gridlock/hrt2 is expressed in the artery-forming angioblasts and it is responsible for the correct segregation of these cells. Thus, induction of Notch signaling is a crucial step in artery formation. How is Notch activity induced in the arterial precursors? It has been shown that hedgehog $(\mathrm{Hh})$ pathway mutants as well as embryos treated with the Hh signaling inhibitor cyclopamine fail to establish arterial identity in the dorsal aorta concomitant with the loss of the arterial marker ephrinB2 (Lawson et al., 2002; Gering and Patient 2005). These embryos lack VEGF expression that it is required for arterial specification, however vegf cannot restore the arterial fate in Notch mutants (Lawson et al., 2002). Taken together this data indicates that, at least in zebrafish, $\mathrm{Hh}$ activates the expression of VEGF, which is upstream of Notch activation during arterial specification. In the mouse, gene-targeting studies confirm most of the findings in zebrafish and support the conservation of this signaling cascade. Definitive hematopoiesis in the embryo is closely associated to arteries (de Bruijn et al., 2000) and it is generally assumed that hematopoietic development is not possible without previous artery specification. This assumption is supported by the absence of hematopoiesis in most arterial-defective mutants and the presence of ectopic hematopoiesis in the vessels of mutants with vein-to-artery conversion, such is the case for COUP-TFII-deficient embryos (You et al., 2005). However, it has not been demonstrated that hematopoiesis cannot occur in the absence of arterial specification. In zebrafish, hematopoietic cells (runx $1^{+}$and/or $c-m y b^{+}$) can originate from vessels that do not express EphrinB2 (EfnB2) after Notch1IC induction (Burns et al., 2005) and some TGF $\beta$-family mutant mouse embryos with arteriovenous malformations (activin receptor like kinase1, ACVRL1, ALK1 (Urness et al., 2000) or endoglin (Urness et al., 2000; Lawson et al., 2001; Lawson et al., 2002) mutants) present ectopic hematopoiesis (CD34+ cells) in veins characterized by the absence of EfnB2 expression. These observations suggest that cells expressing hematopoietic markers are generated in the absence of EfnB2 expression, however whether lack of EfnB2 implies abrogation of arterial specification and if so what is the functional HSC potential of these hematopoietic cells arising in EfnB2-negative vessels, remains unknown.

\section{Notch in the vascular development}

The analysis of different mouse embryos with targeted mutations or carrying Notch-activated transgenes has revealed the importance of the Notch pathway in the regulation of angiogenic development. Most of Notch family mutants develop an homogenous capillary plexus in the yolk sac but lack major angiogenic remodelling of the main vessels (Xue et al., 1999; Krebs et al., 2000). As described above, analysis of Notch mutants in zebrafish first demonstrated the important role of Notch in artery specification (Zhong et al., 2001; Lawson et al., 2002; Gering,Patient 2005). The Notch function in vascular remodelling, including artery specification, is conserved in the mouse being both Notch1 and Notch4 receptors essential albeit some functional redundancy (Conlon et al., 1995; Krebs et al., 2000). Delta4 is the most important Notch ligand in vascular development, although Jagged1 mutants have some vascular defects. Conversely, the transcription factor COUPTFIl inhibits Notch to allow the formation of veins (You et al., 2005). Some of the downstream effectors of Notch signaling in angiogenesis include Gridlock/hrt2 but also EphrinB2 that has recently been identified as a direct Notch-target (Zhong et al., 2000; Timmerman et al., 2004).

In addition to its function in artery versus venous specification, Notch is important in the decision between endothelial and smooth muscle cells, pulmonary versus systemic vessels and large vessels versus capillaries (for an extensive review see (Iso et al., 2003)). One important aspect of vascular remodelling resides in the control of the growing tip when new vessels are formed from the existing ones. Tip cells are specialized endothelial cells that extend filopodia that guide the growth of the sprout blood vessel along VEGF $\alpha$ gradients (Gerhardt et al., 2003; Gerhardt et al., 2004). Notch and Delta4 signaling have been demonstrated to regulate tip cell number, filopodia extension and branching of angiogenic sprouts in HUVEC cells, in the mouse retina and in the hindbrain (Ridgway et al., 2006; Hellstrom et al., 2007; Lobov et al., 2007; Suchting et al., 2007), in the zebrafish embryo (Leslie et al., 2007; Siekmann, Lawson 2007) and in tumors (Noguera-Troise et al., 2006; Scehnet et al., 2007).

Further indicating the relevance of Notch in vascular development, mutations in members of the pathway including the 
Notch ligand Jagged1 and Notch3 are responsible for human diseases that involve vascular defects such as the Alagille and CADASIL syndromes, respectively (reviewed in (Iso et al., 2003)).

\section{Notch in the development of the hematopoietic sys- tem in mammals}

\section{Role of Notch in HSC self-renewal}

There is controversial data on the role of Notch in HSC selfrenewal. On one side, conditional deletion of Notch1, Notch2 or Jagged1 genes induced by Mx-cre in adult bone marrow (Radtke et al., 1999; Mancini et al., 2005; Maillard et al., 2008) or specific expression of a dominant negative mastermindtransgen in fetal liver (Radtke et al., 1999; Mancini et al., 2005; Maillard et al., 2008) have no effect on adult hematopoietic stem cells suggesting that, Notch is dispensable for the maintenance of this cell compartment. However, there are multiple evidences that ex vivo expansion of HSC can be achieved by manipulating the Notch pathway. For example, retroviral transduction of the Notch1IC in the KSL subpopulation (c-Kit+Sca1+Lin' enriched for murine hematopoietic progenitors and HSCs) leads to immortalization of these cells preserving their ability to repopulate myeloid and lymphoid lineages when transplanted into lethally irradiated mice (Varnum-Finney et al., 2000). Ectopic expression of Notch1IC also expands the number of bone marrow repopulating cells in secondary transplants and promotes their lymphoid differentiation (Stier et al., 2002) similar to Notch4IC overexpression in human Lin- cord blood cells (Vercauteren and Sutherland 2004). Moreover, addition of soluble Jagged1 to ex vivo cultures of human CD34+CD38-Lin- cord blood cells expand the number of cells capable to repopulate the hematopoiesis of NOD/SCID mice (Karanu et al., 2000) similar to that found by incubating bone marrow KSL progenitors with a Delta1 fusion protein (VarnumFinney et al., 2003). Moreover, many of these effects are reproduced in CD34-KSL cells retrovirally transduced with hes1, suggesting that this Notch-target gene is responsible for the effects of Notch1 on HSCs self-renewal (Kunisato et al., 2003). Recent work performed by Duncan et al., demonstrated that Notch signaling is active in the KSL subpopulation located in the bone marrow niche and decreases as these cells differentiate. Moreover, Notch inhibition by a dominant negative RBPjк/CSL leads to accelerated differentiation of HSCs in vitro and depletion of HSC activity in vivo indicating that Notch is required for the maintenance of the undifferentiated state of HSCs (Duncan et al., 2005)

Independently of the physiological role of Notch in stem cell maintenance, these results are optimistic about the possibility of targeting Notch in clinical procedures that involve stem cell transplantation or hematopoietic cell therapy.

\section{Notch regulation of lymphoid cell-fate decisions}

Notch signaling regulates several cell-fate decisions in the lymphoid lineage and different studies demonstrate that Notch activation promotes $\mathrm{T}$ - while inhibits $\mathrm{B}$-cell fate from a common progenitor. For example, deletion of $\mathrm{RBPj \kappa /CSL}$ results in increased B-cell differentiation and blockage of T-cell development (Han et al., 2002), conversely, expression of Notch1IC blocks Bcell differentiation and leads to generation of immature $\mathrm{CD} 4^{+} \mathrm{CD} 8^{+}$ T cells (Pui et al., 1999). However, it is still unclear whether this
$B$ - versus $\mathrm{T}$-cell decision takes place in the common lymphoid progenitor (CLP) or in the recently described early T-cell progenitor (ETP) [reviewed in (Maillard et al., 2003)]. Similarly, conditional inactivation of $\mathrm{RBPj \kappa /CSL}$ arrests T-cell development at the DN3 stage, prior to $\beta$-selection (Tanigaki et al., 2004). Following $\beta$-selection, Notch signalling has to be downregulated for differentiation to proceed. In the last step of $\mathrm{CD} 4^{+} \mathrm{CD} 8^{+}$double positive cells, it is unclear whether Notch regulates the decision for generating $\mathrm{CD}^{+}$and $\mathrm{CD}^{+}$single positive (Robey et al., 1996; Izon et al., 2001). Finally, Notch1 also favours the $\alpha \beta$ choice at expenses of the $\gamma \delta$ cell differentiation (Washburn et al., 1997). In addition, Notch2 is required to generate the marginal zone $B$ cells in TCR (T-cell receptor) lineage.

\section{Notch in myeloid differentiation}

Early studies using myeloid cell lines showed that forced Notch1 or Notch2 activation could inhibit myeloid differentiation in a cytokine-dependent manner (Milner et al., 1996; Bigas et al., 1998), likely through expression of Gata2 (Kumano et al., 2001). A similar result was recently reported using isolated KSL population co-cultured on an OP9 stromal cell line expressing Delta1 (de Pooter et al., 2006). In apparent contradiction with in vitro data, the analysis of different conditionally-targeted Notch alleles showed that Notch activity is only required for $\mathrm{T}$ and $\mathrm{B}$ lymphoid differentiation in vivo (Radtke et al., 1999). Nevertheless, it has recently been reported that mice defective in the $\mathrm{FX}$ protein, that converts the GDP-mannose to GDP-fucose, which is required for Fringedependent glycosylation of Notch signalling, develop a myeloproliferative disease. This phenotype has been attributed to a defect in the Notch pathway since fucosylation-deficient myeloid progenitors were not able to respond to Notch-ligands and failed to differentiate compared to the wild type cells (Zhou et al., 2008). Together, these results suggest that Notch is dispensable for myeloid cell generation but its activity is required for the maintenance of myeloid homeostasis in vivo.

\section{Expression of Notch family members in hematopoietic cells}

In agreement with the pleiotropic effects of Notch in hematopoietic cell differentiation, different Notch molecules are expressed in hematopoietic tissues at various stages of development [reviewed in (Ohishi et al., 2003)]. Activation of Notch in hematopoietic precursors is achieved by interactions with stromal supporting cells but also by interactions among hematopoietic cells.

In the adult, Notch1 and Notch2 expression was first detected in the CD34+ ${ }^{+}$in - bone marrow fraction of hematopoietic precursors (Milner et al., 1994; Ohishi et al., 2000), suggesting a role for Notch in hematopoietic progenitor and/or stem cells. Conversely, Notch-ligands Jagged1 (Walker etal., 2001) as well as Delta1 and Delta4 (Karanu et al., 2001) are expressed in the bone marrow stromal cells. Similarly, all three ligands are expressed in thymic epithelial cells, consistent with the important role of Notch in T-cell development (Felli et al., 1999; Mohtashami,Zuniga-Pflucker 2006). In the myeloid lineage, monocytes but not granulocytes express high levels of Notch1 and 2 (Ohishi et al., 2000). Finally, bone marrow erythroid progenitors express Notch1 and its expression decreases in more mature erythroid cells such as acidophilic normoblasts (Ohishi et al., 2000; Walker et al., 2001).

In the embryo, we have previously reported that Notch1 and 
Notch4 receptors together with Jagged1, Jagged2 and Delta4 ligands are expressed in the E9.5-E10.5 aortic endothelium (Robert-Moreno et al., 2005). However, expression of Notch receptors or ligands is not a synonymous of Notch activity since it is the imbalance between them what triggers Notch activation. This was demonstrated by experiments in Drosophila or mouse chimeras in which cells with two wildtype alleles preferentially activated Notch compared to cells with only one Notch allele (Heitzler and Simpson 1991; Washburn et al., 1997). A better indication of Notch activity in the aorta endothelium and the hematopoietic clusters is the expression of its downstream targets hes1, hrt1 and/or hrt2 genes (Fig. 3E) (Robert-Moreno et al., 2005; Robert-Moreno et al., 2008), however since hes1 can be activated by other transcription factors (Curry et al., 2006; Fernandez-Majada et al., 2007), its expression does not necessarily implies Notch activity. Recently a very powerful tool has been developed that is now widely used to assess Notch1 activation. This is the antibody that recognizes Val1744 of the Notch 1 protein, which is the cleavage site of $\gamma$-secretase (Cheng et al., 2003). We have recently shown that cells in both the AGM endothelium and the hematopoietic clusters stain for this antibody indicating that Notch is activated in these cells (Fig. 3D) (RobertMoreno et al., 2008).

\section{Notch implication in the ontogeny of the hematopoietic system}

During the recent years, the function of Notch in embryonic hematopoiesis has partially been elucidated. The first in vivo

A

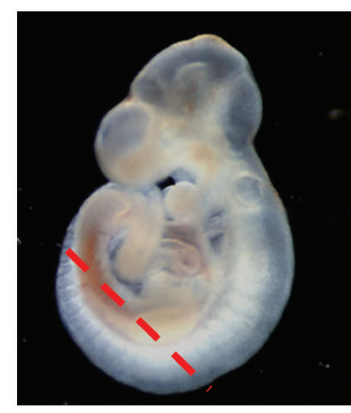

D

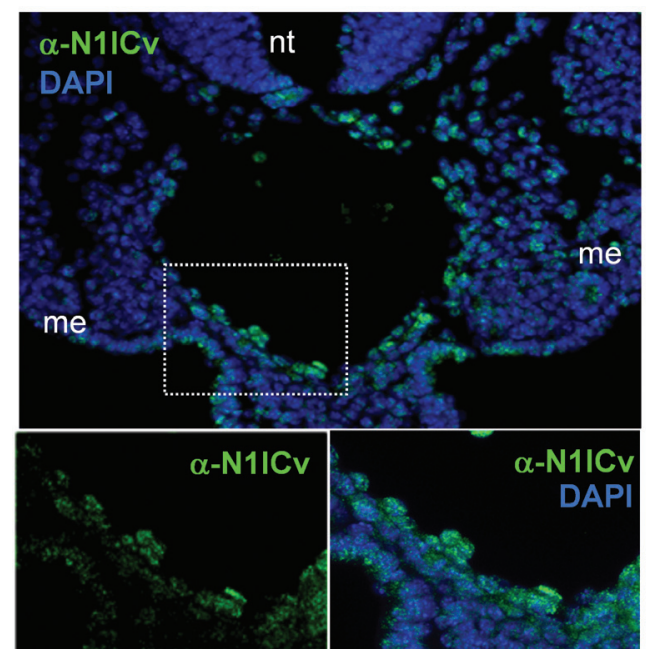

proof that Notch signaling plays a key role in the generation of HSCs during murine embryonic development came from Kumano et al., by studying the Notch1 null embryos. By repopulation experiments in new-born mice, they found that Notch $1^{-/}$yolk sac and embryonic P-Sp lack HSCs, whereas the number of progenitors in the yolk sac was similar in the mutant and the wild type. Despite these hematopoietic defects, E9.5 Notch1 null embryos display a similar number of $\mathrm{CD}_{34}{ }^{+} \mathrm{C}-\mathrm{Kit}^{+}$and $\mathrm{VE}$-cadh ${ }^{+} \mathrm{CD} 45^{-}$in the endothelium in both YS and P-Sp, suggesting a deficiency in the commitment of HSCs from "hemogenic" endothelial cells (Kumano et al., 2003). Further indicating that the absence of Notch signaling was responsible for this phenotype, we described similar abnormalities in the RBPjк/CSL mutant embryos. These embryos completely lack intraembryonic hematopoiesis, but contain a similar number of progenitors in the yolk sac compared to the wild type. In addition, the fused dorsal aorta of the mutants displayed an expansion in the endothelial layer as detected by an increase in the number of cells expressing CD31 and VE-cadherin (Robert-Moreno et al., 2005), suggesting that the endothelial lineage was favoured at expenses of the hematopoietic lineage from a putative common progenitor (hemangioblast) [reviewed in (Dieterlen-Lievre et al., 2006)]. Consistent with the hematopoietic phenotype of Notch pathway mutants, in chimeric mice generated from wildtype and Notch1-deficient ES cells, mutant cells contribute to the yolk sac hematopoiesis but not to the long-term definitive hematopoiesis (Hadland et al., 2004).

Given the fact that Notch is involved in arterial specification through the regulation of ephrin, and arterial differentiation is likely a prerequisite for HSC formation (as previously discussed), it is difficult to separate the contribution of Notch to each of these processes. The best evidence for a specific hematopoietic Notch function in the AGM came from the analysis of the Jagged1-deficient embryos. Although Jagged 1 mutant embryos also have some angiogenic defects, the arterial program is mostly intact as indicates the expression of the arterial markers ephrinB2, CD44 and $\alpha$ SMA. These embryos, however,
E

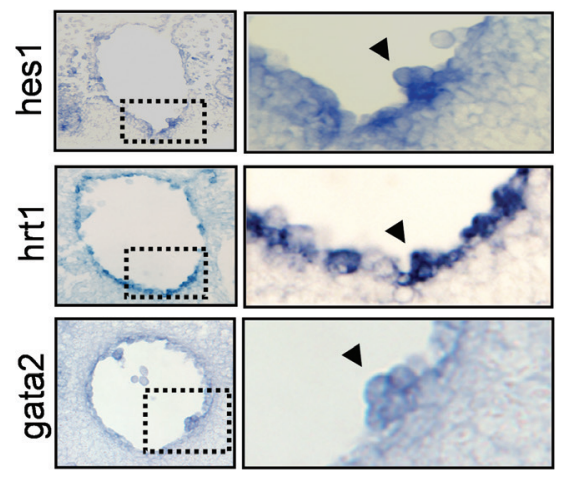

Fig. 3. Notch activity in the AGM region at E10.5. (A) E10.5 mouse embryo. The discontinuous red line marks the section in $B$ in the region of the trunk. (B) Hematoxiline-eosin staining of a transversal section through the trunk region of an E10.5'embryo. The black box shows the region represented in: (C) Representation of the aorta in the AGM region. From E10 to E12.5, clusters of hematopoietic cells appear as budding mainly from the ventral endothelium of the aorta in the AGM region. (D) Active Notch 1 (Val1744) staining in the AGM aorta at E10.5. Lower panels show details of the positive hematopoietic clusters. (E) Detail of in situ hybridization of the Notch-target genes (hes 1, hrt1 and GATA2) showing expression in the aorta endothelium and hematopoietic clusters of the AGM region at E10.5. 
share the intraembryonic hematopoietic defect of the previously analyzed Notch mutants and once again, this mutation does not affect the yolk sac progenitor population ((Robert-Moreno et al., 2008) and unpublished results). Thus, two different Notch signals should be required in the mid-gestation aorta, the first one to establish the arterial fate and the second one to specify the HSC identity. These different signals could be initiated by different Notch receptors or different ligands. In this sense, Notch2, Notch3 and Notch4 mutants show altered vasculogenesis, but defects in embryonic hematopoesis have not been described in any of these mutants (Joutel et al., 1996; Krebs et al., 2000; McCright et al., 2001; Kumano et al., 2003). By expression analysis, others and we found that Notch4 is expressed at E9.5-E10.5 in the aortic endothelium but downregulated in the hematopoietic clusters (Shimizu et al., 2000; Robert-Moreno et al., 2005). However, Notch4-null embryos are viable and only when combined with Notch1-deficiency they display a severe vasculogenic defect (Conlon et al., 1995; Krebs et al., 2000) indicating an overlapping vascular function for Notch1 and Notch4 receptors in this tissue. We also found that not only Jagged1, but also Jagged2 and Delta4 were expressed in the E9.5-10-5 AGM, however we have analyzed the AGM hematopoiesis of the Jagged2 mutants, and it is comparable to the wildtype (Robert-Moreno etal., 2008). Analysis of the hematopoiesis in the Delta4 null embryos has been unsuccessful since this mutation is lethal at E9.5 due to severe vasculogenic defects and loss of endothelial arterial cell fate (Duarte et al., 2004) and in some backgrounds, lethality occurs even in heterozygosity (Krebs et al., 2000). These data together with some unpublished observations suggests that activation of Notch 1 by Delta4 is the right combination to specify vascular development. However, it is not known whether Delta4 plays any role in regulating hematopoietic stem cells in vivo as it has been suggested from in vitro experiments (Dando et al., 2005).

\section{Notch mutant phenotypes in embryonic hematopoiesis: the yolk sac and the AGM}

There are two different waves of yolk sac hematopoiesis that occur before or after circulation is established between the embryo and the yolk sac. It is evident that hematopoietic cells found in the yolk sac before blood circulation (E8.5 in the mouse) are generated in this organ. These are primitive hematopoietic cells and mainly correspond to nucleated red cells and macrophages. As mentioned before, this pre-circulation hematopoiesis is not affected in the Notch-mutant mouse embryos that have been analyzed (Notch1, Notch2, RBPjא/CSL, Jagged1, Jagged2). It is after E8.5, once the circulation is established, that the origin of the hematopoietic progenitors and HSCs residing in the yolk sac or the embryo becomes uncertain. Around E9, several types of myeloid and erythroid progenitors are detected in both the embryo and the yolk sac, and it is also around this time that the first stem cell activity is detected in the embryo and yolk sac by transplantation of busulphan-conditioned new-born mice (Yoder et al., 1997). Interestingly, only this second wave of definitive hematopoiesis is abrogated in the Notch mutant embryos, including Notch1, RBPjк/CSL or Jagged1 knockouts and the stem cell activity is completely lost in the Notch1 mutant embryos (Kumano et al., 2003; Robert-Moreno et al., 2007; Robert-Moreno et al., 2008). Together this data supports the idea that there are two well-differentiated genetic programs responsible for embryonic hematopoiesis, being one Notch-dependent and the other Notchindependent. More accurate cell tracing experiments will be required to demonstrate the yolk sac or the intraembryonic origin of definitive HSCs, however, and independent of where HSCs are originated, they require Notch signaling to exist.

\section{Notch signaling modulates red cell homeostasis in the yolk sac}

As previously mentioned, pre- and post-circulation hematopoiesis in the yolk sac of $\mathrm{RBPj \kappa /CSL}$ null embryos is apparently normal (Robert-Moreno et al., 2007). Nevertheless, when we analyzed the erythroid Ter119+ cells in the blood islands of the RBPjк null yolk sacs, we found an increase in the percentage and number of these cells that was attributed to reduced apoptosis. Consistently, we detected changes in the level of several prosurvival genes in the mutant cells, although part of the phenotype could be also explained by architectural defects in the yolk sac that leads to reduced oxygen availability. Nevertheless, incubation of wildtype yolk sac cells with the $\gamma$-secretase inhibitor DAPT resulted in a comparable decrease in the apoptosis of Ter119+ cells in vitro, strongly supporting a function for Notch in regulating apoptosis in the erythroid lineage (Robert-Moreno et al., 2007).

\section{Notch target genes}

Despite the multiple and diverse effects that Notch plays during embryogenesis and adult tissue homeostasis, to date only a few Notch target genes have been identified. This includes the wellcharacterized hes 1 and hes-related genes [reviewed in (Jarriault et al., 1995; Iso et al., 2003) and the newly identified targets ephrinB2 in heart development (Timmerman et al., 2004), c-myc in T-cell lymphoma (Weng et al., 2006) or gata3 and il-4 in T cells (Amsen et al., 2004; Dontje et al., 2006). Interestingly, most of these recently identified targets only depend on Notch in specific tissues suggesting that its cooperation with other tissue specific factors is a general mechanism of Notch function. In the embryonic aorta, RBPjк/CSL mutant embryos lack expression of at least three master hematopoietic transcription factors (Runx1, Gata2 and Scl) (Robert-Moreno et al., 2005). Lack of gata2 expression was also found in the aortic endothelium of Jag1 null embryos (Robert-Moreno et al., 2008). Although this may be a secondary effect of the hematopoietic defficiency, we found by chromatin immunoprecipitation experiments, from both myeloid progenitors (the 32D cell line) and E9.5 embryos, that gata2 was a direct target of Notch1/RBPjк (Robert-Moreno et al., 2005). Interestingly,

\section{Hematopoietic cluster}

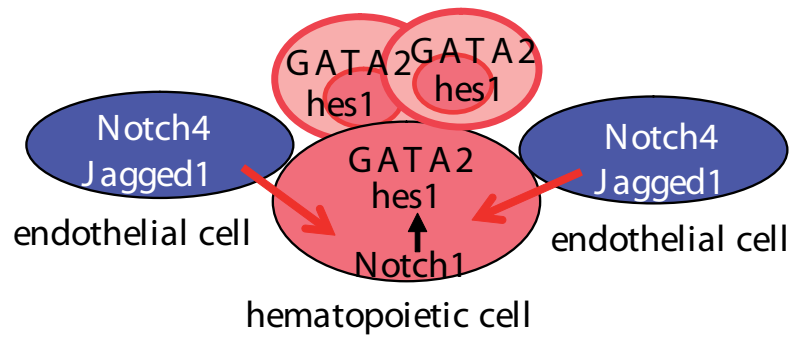

Fig. 4. Model for Notch signaling and downstream molecules involved in the determination of hematopoietic specification in the dorsal aorta. 
gata2 had been previously identified as a Notch-dependent gene in 32D myeloid progenitor cells and F5-5 erythroleukemia cells (Kumano et al., 2001; Robert-Moreno et al., 2008). In contrast to our data, the authors proposed in this report that it is the Notchtarget hes 1 , which maintains gata2 expression under differentiating conditions.

The hematopoietic transcription factor Runx1/Aml1 is absolutely required for the generation of HSCs from the aortic endothelium (Okuda et al., 1996; North et al., 1999; Chen et al., 2009). Runx1 has been recently described to act downstream of Notch in the establishment of the hematopoietic stem cell fate in the zebrafish embryo (Burns et al., 2005). In addition, ectopic expression of runx1 (but not gata2 or scl) partially rescues the hematopoietic defects of Notch 1 - AGM-derived cells in vitro(Nakagawa et al., 2006). Although there is no evidence for a direct effect of Notch on the runx1 gene (Robert-Moreno et al., 2005), it is possible that Notch regulates runx1 downstream of gata2 (Nottingham et al., 2007). However we found that runx1 is expressed in $50 \%$ of the Jagged 1 null embryos in which gata2 is absent. Moreover we have been able to partially rescue the hematopoietic defect of Jagged1 null cells by ectopic expression of gata2 (Kumano et al., 2001; Robert-Moreno et al., 2008), further supporting a role for Notch in specifically regulating embryonic hematopoiesis through gata2.

The classical Notch-targets hes 1 and hes-related genes are also expressed in the endothelium lining the dorsal aorta and in hematopoietic clusters (Robert-Moreno et al., 2005; RobertMoreno et al., 2008) suggesting that they play a role in this system (Fig. 3E). In agreement with this, Hes1 has been shown to inhibit differentiation and maintain HSCs (Kunisato et al., 2003).

Together this data leads to speculate that different Notch downstream effectors, including general regulators such as hes 1 , but also tissue specific such as gata2, may cooperate in the acquisition of specific stem cell traits to generate, maintain or amplify HSCs in the embryo (Fig. 4).

\section{Notch functions in the hematopoietic development of zebrafish}

The use of zebrafish has been a major advance in the research of embryonic hematopoiesis. The main advantage of this system is the transparency of the embryos and the similarity between mammals and fishes in the molecular programs that control hematopoiesis (Langenau et al., 2003; Davidson,Zon 2004).

In zebrafish, primitive hematopoiesis does not occur in extraembryonic tissue as in mammals, instead, primitive erythroblasts are generated in the intermediate cell mass of Oellacher, ventral to the notochord and placed in the trunk (Fouquet et al., 1997; Herbomel,Levraud 2005). However, definitive hematopoiesis takes place on the floor of the dorsal aorta, as in vertebrates. The signalling pathways that controls hematopoiesis have been nicely characterized in this organism: secreted hedgehog from the floor plate, notochord and hypochord is at the top of this cascade, leading to the induction of vegf expression, which is upstream of Notch (Lawson et al., 2002; Gering,Patient 2005). Then, Notch induces the arterial specification through regulation of gridlock (Zhong et al., 2001) and the establishment of the definitive hematopoietic program, upstream of runx1 (Burns et al., 2005). This essential role of Notch signalling in zebrafish hematopoiesis has been mainly characterized by the study of Mind bomb mutants, and has been confirmed by using $\gamma$-secretase inhibitors in vivo (Gering,Patient 2005; Lee et al., 2009). Mind bombis an E3Ubiquitin ligase required for Delta maturation and Notch/Delta interaction. Mind bomb mutants display normal primitive hematopoiesis but impaired HSC development. Consistent with this, cmyb and runx 1 express aorta of these mutants, while ectopic notch1 activation results in an expansion in the number of HSCs, dependent on Runx1 (Burns et al., 2005). More recently, similar results for mind bomb gene have been reported in the mouse embryo (Yoon et al., 2008).

From all this data we can conclude that zebrafish and murine hematopoiesis share the requirement of Notch signaling for definitive but not for primitive hematopoiesis (Burns et al., 2005: Gering and Patient 2005).

\section{Notch function during development of hematopoietic system in Drosophila}

In the fly, Notch participates at least in two different phases during hematopoietic development (Lebestky etal., 2003; Mandal et al., 2004). The first one occurs in the Drosophila larvae, where cardiogenic mesoderm gives rise to nephrocytes (excretory), cardioblasts (vascular) and blood cells. Notch loss-of-function results in a decrease of nephrocytes and blood cells with an increase in the vascular fate indicating that Notch is required for blood cell specification (Mandal et al., 2004). The second one takes place during adult fly hematopoiesis. This process occurs in a bilateral chain of tight clustered cells ( 20 cells approximately) flanking the lymph gland, a structure comparable to the dorsal aorta. Drosophila blood cells, called hemocytes, are divided into plasmatocytes, analogous to the vertebrate macrophages, and crystal cells, involved in the melanization of pathogens (Rizki,Rizki 1959; Hartenstein et al., 1992). The Drosophila GATA homolog serpent, participates in the generation of both types of hemocytes, whereas the Runx1 homolog lozenge is only required for the specification of crystal cell precursors (Lebestky et al., 2000). Similar to what occurs in mice, Notch induces serpentexpression in Drosophila (Mandal et al., 2004) that is essential for the expression of lozenge (Lebestky et al., 2000; Nottingham et al., 2007)

\section{Altered Notch signaling in human disease}

Three different congenital diseases due to mutations in Notch family members have been described. Mutations in the Jagged 1 gene are responsible for Alagille syndrome, which results in impaired generation and disfunction of different organs such as heart, eye, liver and skeleton (Li et al., 1997). Delta3 mutations are responsible for spondylocostal dysostosis, a developmental disease characterized by rib fusion and trunk dwarfism (Bulman et al., 2000). Finally, mutations in the extracellular EGF-like repeats of Notch3 results in Cerebral Autosomal Dominant Arteriopathy with Subcortical Infarcts and Leukoencephalopathy (CADASIL), characterized by migraines, strokes and dementia, further supporting that Notch is involved in vascular and neural development in humans (Joutel et al., 1996). Notch also participates in tumorigenic processes in different tissues including mammary gland, skin, cervix and prostate [reviewed in (Lai 
2004)], colon (van Es et al., 2005) (Fernandez-Majada et al., 2007; Rodilla et al., 2009) or pancreas (Miyamoto et al., 2003).

\section{Hematopoietic disorders}

The human Notch1 gene was first identified in a T-cell leukaemia as a translocation that involves the TCR. This resulted in a chimeric protein containing the extracellular domain of TCR- $\beta$ fused to Notch1IC leading to constitutive Notch activation in T cells (Ellisen et al., 1991). Although this rearrangement is a rare event, there is now evidence that point mutations occurring in the heterodimerization domain of Notch, that facilitates ligand-independent activation, or in the PEST domain, resulting in a more stable Notch1IC protein, are present in $50 \%$ of human T-ALL (Weng et al., 2004). Moreover, different factors are known to cooperate with Notch in T-leukemogenesis including downstream targets such as c-myc (Palomero et al., 2006) or NFKB (Vilimas et al., 2007), however there are evidences that hes 1 can reproduce the effects of Notch in promoting leukemias (Kawamata et al., 2002). In B cells, Epstein-Barr virus or Kaposi's sarcoma-associated herpes viruses are known to activate Notch-target genes through viral proteins that bind to the RBPjк/CSL consensus thus leading to cell immortalization and transformation [reviewed in (Milner and Bigas 1999)].

\section{Pleiotropy and context specificity of Notch in adult versus embryonic hematopoietic stem cells}

The mechanisms leading to the context specific functions of Notch may include 1) differences in the expression of Notch receptors (Cheng et al., 2007), 2) accesibility of the Notchpresenting cell to different Notch ligands (Robert-Moreno et al., $2005), 3$ ) changes in the receptor-ligand affinity due to modification of the receptors by fringe glycosyltransferases (Hicks et al., 2000; Moloney et al., 2000), 4) ubiquitination of the ligands (BenYaacov et al., 2001; Bardin and Schweisguth 2006; De Renzis et al., 2006) or 5) cooperation of Notch with tissue specific factors. All these variables are responsible for the wide range of Notch effects that are observed depending on the temporal phase, the tissue, and the cell type, among others. In general, Notch activation inhibits differentiation through hes and hrt transcriptional repressors [reviewed in (Artavanis-Tsakonas et al., 1999)], however it may induce differentiation in some specific tissues. For example, in keratinocytes Notch promotes cell cycle arrest and terminal differentiation by inducing p21 expression (Rangarajan et al., 2001).

In embryonic hematopoiesis, Notch may induce the hematopoietic fate through gata2 while maintaining the stemness through hes 1 . The high complexity of the hematopoietic process, including the expanded period of time when it occurs and the number of organs and cell types that are involved, may be responsible for the different and controversial effects that have been reported for Notch in this tissue.

\section{Remarks}

Generation, expansion and manipulation of HSC are the main challenges in clinical transplantation and regenerative medicine. As shown in this review, Notch signaling plays a crucial role in the ontogeny and maintenance of the hematopoietic system in both the embryo and the adult. Based on this, it is tempting to speculate that targeting the Notch pathway will be a valuable tool in HSCbased therapies. On the other side of the coin, we should be extremely cautious when manipulating this pathway since Notch activation precedes many tumorigenic processes including hematologic malignancies.

\section{Acknowledgements}

Thanks to Julia Inglés-Esteve for critical reading of the manuscript $A R M$ is an investigator of the Juan de la Cierva program. $L E$ is an investigator of ISCIII program (02/30279). This Research was funded by Ministerio Educación y Ciencia (SAF2007/60080) and RTICC/FEDER (RD06/0020/0098). We would like to apologize to the authors whose contributions to this subject has not been cited due to space limitation.

\section{References}

AMSEN, D., BLANDER, J.M., LEE, G.R., TANIGAKI, K., HONJO, T. and FLAVELL, R.A. (2004). Instruction of distinct CD4 T helper cell fates by different notch ligands on antigen-presenting cells. Ce//117: 515-526.

ARTAVANIS TSAKONAS, S., MATSUNO, K. and FORTINI, M.E. (1995). Notch signaling. Science 225-232.

ARTAVANIS-TSAKONAS, S., RAND, M.D. and LAKE, R.J. (1999). Notch signaling: cell fate control and signal integration in development. Science 284: 770776 .

BARDIN, A.J. and SCHWEISGUTH, F. (2006). Bearded family members inhibit Neuralized-mediated endocytosis and signaling activity of Delta in Drosophila Dev Cel/10: 245-255.

BEN-YAACOV, S., LE BORGNE, R., ABRAMSON, I., SCHWEISGUTH, F. and SCHEJTER, E.D. (2001). Wasp, the Drosophila Wiskott-Aldrich Syndrome Gene Homologue, Is Required for Cell Fate Decisions Mediated by Notch Signaling. J Cel/ Bio/152: 1-14

BERTRAND, J.Y., GIROUX, S., GOLUB, R., KLAINE, M., JALIL, A., BOUCONTET, L., GODIN, I. and CUMANO, A. (2005). Characterization of purified intraembryonic hematopoietic stem cells as a tool to define their site of origin. Proc Nat/ Acad SciUS A 102: 134-139.

BIGAS, A., MARTIN, D.I. and MILNER, L.A. (1998). Notch1 and Notch2 inhibit myeloid differentiation in response to different cytokines. Mol. Cel/ Bio/18:23242333.

BOISSET, J.C., VAN CAPPELLEN, W., ANDRIEU-SOLER, C., GALJART, N., DZIERZAK, E. and ROBIN, C. (2010). In vivo imaging of haematopoietic cells emerging from the mouse aortic endothelium. Nature 464: 116-120.

BULMAN, M.P., KUSUMI, K., FRAYLING, T.M., MCKEOWN, C., GARRETT, C. LANDER, E.S., KRUMLAUF, R., HATTERSLEY, A.T., ELLARD, S. and TURNPENNY, P.D. (2000). Mutations in the human delta homologue, DLL3, cause axial skeletal defects in spondylocostal dysostosis. Nat Genet 24: 438441.

BURNS, C.E., TRAVER, D., MAYHALL, E., SHEPARD, J.L. and ZON, L.I. (2005). Hematopoietic stem cell fate is established by the Notch-Runx pathway. Genes Dev 19: 2331-2342.

CHEN, M.J., YOKOMIZO, T., ZEIGLER, B.M., DZIERZAK, E. and SPECK, N.A. (2009). Runx1 is required for the endothelial to haematopoietic cell transition but not thereafter. Nature 457: 887-891.

CHENG, H.T., KIM, M., VALERIUS, M.T., SURENDRAN, K., SCHUSTERGOSSLER, K., GOSSLER, A., MCMAHON, A.P. and KOPAN, R. (2007). Notch2, but not Notch1, is required for proximal fate acquisition in the mammalian nephron. Development 134: 801-811.

CHENG, H.T., MINER, J.H., LIN, M., TANSEY, M.G., ROTH, K. and KOPAN, R (2003). Gamma-secretase activity is dispensable for mesenchyme-to-epithelium transition but required for podocyte and proximal tubule formation in developing mouse kidney. Development 130: 5031-5042.

CHO, K.O. and CHOI, K.W. (1998). Fringe is essential for mirror symmetry and morphogenesis in the Drosophila eye. Nature 396: 272-26.

CONLON, R.A., REAUME, A.G. and ROSSANT, J. (1995). Notch1 is required for 
the coordinate segmentation of somites. Development 121: 1533-1545.

CORBEL, C., SALAUN, J., BELO-DIABANGOUAYA, P. and DIETERLEN-LIEVRE, F. (2007). Hematopoietic potential of the pre-fusion allantois. Dev Bio/301: 478488.

COUSO, J.P., KNUST, E. and MARTINEZ ARIAS, A. (1995). Serrate and wingless cooperate to induce vestigial gene expression and wing formation in Drosophila. Curr Bio/5: 1437-1448.

CUMANO, A., DIETERLEN-LIEVRE, F. and GODIN, I. (1996). Lymphoid potential, probed before circulation in mouse, is restricted to caudal intraembryonic splanchnopleura. Ce//86: 907-916.

CURRY, C.L., REED, L.L., NICKOLOFF, B.J., MIELE, L. and FOREMAN, K.E. (2006). Notch-independent regulation of Hes-1 expression by c-Jun N-terminal kinase signaling in human endothelial cells. Lab Invest 86: 842-852.

DALE, J.K., MAROTO, M., DEQUEANT, M.L., MALAPERT, P., MCGREW, M. and POURQUIE, O. (2003). Periodic notch inhibition by lunatic fringe underlies the chick segmentation clock. Nature 421: 275-278.

DANDO, J.S., TAVIAN, M., CATELAIN, C., POIRAULT, S., BENNACEURGRISCELLI, A., SAINTENY, F., VAINCHENKER, W., PEAULT, B. and LAURET, E. (2005). Notch/Delta4 interaction in human embryonic liver CD34+ CD38cells: positive influence on BFU-E production and LTC-IC potential maintenance. Stem Cells 23: 550-560.

DAVIDSON, A.J. and ZON, L.I. (2004). The 'definitive' (and 'primitive') guide to zebrafish hematopoiesis.' Oncogene 23: 7233-7246.

DE BRUIJN, M.F., MA, X., ROBIN, C., OTTERSBACH, K., SANCHEZ, M.J. and DZIERZAK, E. (2002). Hematopoietic stem cells localize to the endothelial cell layer in the midgestation mouse aorta. Immunity 16: 673-683.

DE BRUIJN, M.F., PEETERS, M.C., LUTEIJN, T., VISSER, P., SPECK, N.A. and DZIERZAK, E. (2000a). Definitive hematopoietic stem cells first develop within the major arterial regions of the mouse embryo. Blood 96: 2902-2904.

DE BRUIJN, M.F., SPECK, N.A., PEETERS, M.C. and DZIERZAK, E. (2000b). Definitive hematopoietic stem cells first develop within the major arterial regions of the mouse embryo. Embo J19: 2465-2474.

DE POOTER, R.F., SCHMITT, T.M., DE LA POMPA, J.L., FUJIWARA, Y., ORKIN, S.H. and ZUNIGA-PFLUCKER, J.C. (2006). Notch signaling requires GATA-2 to inhibit myelopoiesis from embryonic stem cells and primary hemopoietic progenitors. J Immuno/176: 5267-5275.

DE RENZIS, S., YU, J., ZINZEN, R. and WIESCHAUS, E. (2006). Dorsal-ventral pattern of Delta trafficking is established by a Snail-Tom-Neuralized pathway. Dev Cel/10: 257-264.

DEXTER, G. (1914). The analysis of a case of continuous variation in" Drosophila by a study of its linkage relation. The American Journalist 48: 712-758.

DIETERLEN-LIEVRE, F., GODIN, I. and PARDANAUD, L. (1997). Where do hematopoietic stem cells come from? Int Arch Allergy Immuno/112: 3-8.

DieTERLEN-LIEVRE, F., POUGeT, C., BOLLEROT, K. and JAFFREDO, T. (2006). Are intra-aortic hemopoietic cells derived from endothelial cells during ontogeny? Trends Cardiovasc Med16: 128-139.

DONTJE, W., SCHOTTE, R., CUPEDO, T., NAGASAWA, M., SCHEEREN, F., GIMENO, R., SPITS, H. and BLOM, B. (2006). Delta-like1-induced Notch1 signaling regulates the human plasmacytoid dendritic cell versus $T$-cell lineage decision through control of GATA-3 and Spi-B. Blood 107: 2446-2452.

DUARTE, A., HIRASHIMA, M., BENEDITO, R., TRINDADE, A., DINIZ, P., BEKMAN, E., COSTA, L., HENRIQUE, D. and ROSSANT, J. (2004). Dosage-sensitive requirement for mouse DII4 in artery development. Genes Dev18: 2474-2478.

DUNCAN, A.W., RATTIS, F.M., DIMASCIO, L.N., CONGDON, K.L., PAZIANOS, G., ZHAO, C., YOON, K., COOK, J.M., WILLERT, K., GAIANO, N. et al. (2005). Integration of Notch and Wnt signaling in hematopoietic stem cell maintenance. Nat Immuno/6: 314-322.

EICHMANN, A., CORBEL, C., NATAF, V., VAIGOT, P., BREANT, C. and LE DOUARIN, N.M. (1997). Ligand-dependent development of the endothelial and hemopoietic lineages from embryonic mesodermal cells expressing vascular endothelial growth factor receptor 2. Proc Nat/ Acad Sci U S A 94: 5141-5146.

ELLISEN, L.W., BIRD, J., WEST, D.C., SORENG, A.L., REYNOLDS, T.C., SMITH, S.D. and SKLAR, J. (1991). TAN-1, the human homolog of the Drosophilanotch gene, is broken by chromosomal translocations in T lymphoblastic neoplasms. Cel/66: 649-661.
FELLI, M.P., MARODER, M., MITSIADIS, T.A., CAMPESE, A.F., BELLAVIA, D. VACCA, A., MANN, R.S., FRATI, L., LENDAHL, U., GULINO, A. et al. (1999). Expression pattern of notch1, 2 and 3 and Jagged 1 and 2 in lymphoid and stromal thymus components: distinct ligand-receptor interactions in intrathymic T cell development. Int Immuno/11: 1017-1025

FERNANDEZ-MAJADA, V., AGUILERA, C., VILLANUEVA, A., VILARDELL, F., ROBERT-MORENO, A., AYTES, A., REAL, F.X., CAPELLA, G., MAYO, M.W., ESPINOSA, L. et al. (2007a). Nuclear IKK activity leads to dysregulated notchdependent gene expression in colorectal cancer. Proc Nat/Acad SciUSA104: 276-281.

FERNANDEZ-MAJADA, V., PUJADAS, J., VILARDELL, F., CAPELLA, G., MAYO, M.W., BIGAS, A. and ESPINOSA, L. (2007b). Aberrant cytoplasmic localization of N-CoR in colorectal tumors. Cell Cycle 6: 1748-1752.

FOUQUET, B., WEINSTEIN, B.M., SERLUCA, F.C. and FISHMAN, M.C. (1997). Vessel patterning in the embryo of the zebrafish: guidance by notochord. Dev Biol183: 37-48.

FRYER, C.J., LAMAR, E., TURBACHOVA, I., KINTNER, C. and JONES, K.A (2002). Mastermind mediates chromatin-specific transcription and turnover of the Notch enhancer complex. Genes Dev 16: 1397-1411.

GARCIA-PORRERO, J.A., GODIN, I.E. and DIETERLEN-LIEVRE, F. (1995). Potential intraembryonic hemogenic sites at pre-liver stages in the mouse. Anat Embryol (Berl) 192: 425-435.

GEKAS, C., DIETERLEN-LIEVRE, F., ORKIN, S.H. and MIKKOLA, H.K. (2005) The placenta is a niche for hematopoietic stem cells. Dev Cel/8: 365-375.

GERHARDT, H., GOLDING, M., FRUTTIGER, M., RUHRBERG, C., LUNDKVIST, A., ABRAMSSON, A., JELTSCH, M., MITCHELL, C., ALITALO, K., SHIMA, D. et al. (2003). VEGF guides angiogenic sprouting utilizing endothelial tip cell filopodia. J Cel/ Bio/161: 1163-1177.

GERHARDT, H., RUHRBERG, C., ABRAMSSON, A., FUJISAWA, H., SHIMA, D. and BETSHOLTZ, C. (2004). Neuropilin-1 is required for endothelial tip cell guidance in the developing central nervous system. Dev Dyn 231: 503-509.

GERING, M. and PATIENT, R. (2005). Hedgehog signaling is required for adult blood stem cell formation in zebrafish embryos. Dev Ce//8: 389-400.

GODIN, I. and CUMANO, A. (2002). The hare and the tortoise: an embryonic haematopoietic race. Nat Rev Immuno/2: 593-604.

GODIN, I., DIETERLEN-LIEVRE, F. and CUMANO, A. (1995). Emergence of multipotent hemopoietic cells in the yolk sac and paraaortic splanchnopleura in mouse embryos, beginning at 8.5 days postcoitus. Proc Nat/Acad SciUSA92: 773-777.

GODIN, I., GARCIA-PORRERO, J.A., DIETERLEN-LIEVRE, F. and CUMANO, A. (1999). Stem cell emergence and hemopoietic activity are incompatible in mouse intraembryonic sites. J EXp Med 190: 43-52.

HADLAND, B.K., HUPPERT, S.S., KANUNGO, J., XUE, Y., JIANG, R., GRIDLEY, T., CONLON, R.A., CHENG, A.M., KOPAN, R. and LONGMORE, G.D. (2004). $A$ requirement for Notch1 distinguishes 2 phases of definitive hematopoiesis during development. Blood104: 3097-3105.

HAMAGUCHI, I., HUANG, X.L., TAKAKURA, N., TADA, J., YAMAGUCHI, Y. KODAMA, H. and SUDA, T. (1999). In vitro hematopoietic and endothelial cell development from cells expressing TEK receptor in murine aorta-gonadmesonephros region. Blood 93: 1549-1556.

HAN, H., TANIGAKI, K., YAMAMOTO, N., KURODA, K., YOSHIMOTO, M., NAKAHATA, T., IKUTA, K. and HONJO, T. (2002). Inducible gene knockout of transcription factor recombination signal binding protein-J reveals its essential role in $\mathrm{T}$ versus $\mathrm{B}$ lineage decision. Int Immuno/14: 637-645.

HARTENSTEIN, A.Y., RUGENDORFF, A., TEPASS, U. and HARTENSTEIN, V. (1992). The function of the neurogenic genes during epithelial development in the Drosophila embryo. Development1203-1220.

HEITZLER, P. and SIMPSON, P. (1991). The choice of cell fate in the epidermis of Drosophila. Cel/64: 1083-1092.

HELLSTROM, M., PHNG, L.K., HOFMANN, J.J., WALLGARD, E., COULTAS, L., LINDBLOM, P., ALVA, J., NILSSON, A.K., KARLSSON, L., GAIANO, N. et al. (2007). DIl4 signalling through Notch1 regulates formation of tip cells during angiogenesis. Nature 445: 776-780.

HERBOMEL, P. and LEVRAUD, J.P. (2005). Imaging early macrophage differentiation, migration, and behaviors in live zebrafish embryos. Methods Mol Med 105: 199-214. 
HICKS, C., JOHNSTON, S.H., DISIBIO, G., COLLAZO, A., VOGT, T.F. and WEINMASTER, G. (2000). Fringe differentially modulates Jagged1 and Delta1 signalling through Notch1 and Notch2. Nat Cel/ Bio/2: 515-520.

HIRATA, H., OHTSUKA, T., BESSHO, Y. and KAGEYAMA, R. (2000). Generation of structurally and functionally distinct factors from the basic helix-loop-helix gene Hes3 by alternative first exons. J Biol Chem 275: 19083-19089.

HSU, H.C., EMA, H., OSAWA, M., NAKAMURA, Y., SUDA, T. and NAKAUCHI, H. (2000). Hematopoietic stem cells express Tie-2 receptor in the murine fetal liver. Blood 96: 3757-3762.

HUBER, M.A., AZOITEI, N., BAUMANN, B., GRUNERT, S., SOMMER, A., PEHAMBERGER, H., KRAUT, N., BEUG, H. and WIRTH, T. (2004a). NFkappaB is essential for epithelial-mesenchymal transition and metastasis in a model of breast cancer progression. J Clin Invest 114: 569-581.

HUBER, T.L., KOUSKOFF, V., FEHLING, H.J., PALIS, J. and KELLER, G. (2004b). Haemangioblast commitment is initiated in the primitive streak of the mouse embryo. Nature 432: 625-630.

IRVINE, K.D. (1999). Fringe, Notch, and making developmental boundaries. Curr Opin Genet Dev 9: 434-441.

ISO, T., HAMAMORI, Y. and KEDES, L. (2003a). Notch signaling in vascular development. Arterioscler Thromb Vasc Bio/23: 543-553.

ISO, T., KEDES, L. and HAMAMORI, Y. (2003b). HES and HERP families: multiple effectors of the Notch signaling pathway. J Cell Physio/ 194: 237-255.

ITOH, M., KIM, C.H., PALARDY, G., ODA, T., JIANG, Y.J., MAUST, D., YEO, S.Y., LORICK, K., WRIGHT, G.J., ARIZA-MCNAUGHTON, L. et al. (2003). Mind bomb is a ubiquitin ligase that is essential for efficient activation of Notch signaling by Delta. Dev Ce//4: 67-82.

IZON, D.J., PUNT, J.A., XU, L., KARNELL, F.G., ALLMAN, D., MYUNG, P.S., BOERTH, N.J., PUI, J.C., KORETZKY, G.A. and PEAR, W.S. (2001). Notch1 regulates maturation of $C D 4+$ and $C D 8+$ thymocytes by modulating TCR signal strength. Immunity 14: 253-264.

JARRIAULT, S., BROU, C., LOGEAT, F., SCHROETER, E.H., KOPAN, R. and ISRAEL, A. (1995). Signalling downstream of activated mammalian Notch. Nature 377: 355-358.

JOUTEL, A., CORPECHOT, C., DUCROS, A., VAHEDI, K., CHABRIAT, H., MOUTON, P., ALAMOWITCH, S., DOMENGA, V., CECILLION, M., MARECHAL, E. et al. (1996). Notch3 mutations in cadasil, a hereditary adult-onset condition causing stroke and dementia [see comments]. Nature 383: 707-710.

KAO, H.Y., ORDENTLICH, P., KOYANO-NAKAGAWA, N., TANG, Z., DOWNES, M., KINTNER, C.R., EVANS, R.M. and KADESCH, T. (1998). A histone deacetylase corepressor complex regulates the Notch signal transduction pathway. Genes and Development 12: 2269-2277.

KARANU, F.N., MURDOCH, B., GALLACHER, L., WU, D.M., KOREMOTO, M., SAKANO, S. and BHATIA, M. (2000). The notch ligand jagged-1 represents a novel growth factor of human hematopoietic stem cells. J Exp Med 192: 13651372.

KARANU, F.N., MURDOCH, B., MIYABAYASHI, T., OHNO, M., KOREMOTO, M., GALLACHER, L., WU, D., ITOH, A., SAKANO, S. and BHATIA, M. (2001). Human homologues of Delta- 1 and Delta-4 function as mitogenic regulators of primitive human hematopoietic cells. Blood 97: 1960-1967.

KAUFMAN, M.H. (1994). The atlas of mouse development, Academic Press, San Diego, CA, 1992, 512 pp. Molec. Reprod. Dev. 37: 120.

KAWAMATA, S., DU, C., LI, K. and LAVAU, C. (2002). Overexpression of the Notch target genes Hes in vivo induces lymphoid and myeloid alterations. Oncogene 21: 3855-3863.

KISSA, K. and HERBOMEL, P. (2010). Blood stem cells emerge from aortic endothelium by a novel type of cell transition. Nature 464: 112-115.

KOPAN, R., SCHROETER, E.H., WEINTRAUB, H. and NYE, J.S. (1996). Signal transduction by activated mNotch: importance of proteolytic processing and its regulation by the extracellular domain. Proc Nat/ Acad SciU SA93: 1683-1688.

KREBS, L.T., XUE, Y., NORTON, C.R., SHUTTER, J.R., MAGUIRE, M., SUNDBERG, J.P., GALLAHAN, D., CLOSSON, V., KITAJEWSKI, J., CALLAHAN, R. et al. (2000). Notch signaling is essential for vascular morphogenesis in mice. Genes Dev 14: 1343-1352.

KUMANO, K., CHIBA, S., KUNISATO, A., SATA, M., SAITO, T., NAKAGAMIYAMAGUCHI, E., YAMAGUCHI, T., MASUDA, S., SHIMIZU, K., TAKAHASHI, T. et al. (2003). Notch1 but not Notch2 is essential for generating hematopoietic stem cells from endothelial cells. Immunity 18: 699-711.

KUMANO, K., CHIBA, S., SHIMIZU, K., YAMAGATA, T., HOSOYA, N., SAITO, T., TAKAHASHI, T., HAMADA, Y. and HIRAI, H. (2001). Notch1 inhibits differentiation of hematopoietic cells by sustaining GATA-2 expression. Blood98: 32833289.

KUMARAVELU, P., HOOK, L., MORRISON, A.M., URE, J., ZHAO, S., ZUYEV, S., ANSELL, J. and MEDVINSKY, A. (2002). Quantitative developmental anatomy of definitive haematopoietic stem cells/long-term repopulating units (HSC/ $\mathrm{RUs}$ ): role of the aorta-gonad-mesonephros (AGM) region and the yolk sac in colonisation of the mouse embryonic liver. Development 129: 4891-4899.

KUNISATO, A., CHIBA, S., NAKAGAMI-YAMAGUCHI, E., KUMANO, K., SAITO, T., MASUDA, S., YAMAGUCHI, T., OSAWA, M., KAGEYAMA, R., NAKAUCHI, H. et al. (2003). HES-1 preserves purified hematopoietic stem cells ex vivo and accumulates side population cells in vivo. Blood 101: 1777-1783.

LAI, E.C. (2004). Notch signaling: control of cell communication and cell fate. Development 131: 965-973.

LAI, E.C., DEBLANDRE, G.A., KINTNER, C. and RUBIN, G.M. (2001). Drosophila neuralized is a ubiquitin ligase that promotes the internalization and degradation of delta. Dev Cel/1: 783-794.

LAM, E.Y., HALL, C.J., CROSIER, P.S., CROSIER, K.E. and FLORES, M.V. (in press). Live imaging of Runx1 expression in the dorsal aorta tracks the emergence of blood progenitors from endothelial cells. Blood DOI: 10.1182/ blood-2010-01-264382

LANGENAU, D.M., TRAVER, D., FERRANDO, A.A., KUTOK, J.L., ASTER, J.C., KANKI, J.P., LIN, S., PROCHOWNIK, E., TREDE, N.S., ZON, L.I. et al. (2003). Myc-induced T cell leukemia in transgenic zebrafish. Science 299: 887-890.

LASSILA, O., ESKOLA, J., TOIVANEN, P., MARTIN, C. and DIETERLEN-LIEVRE, F. (1978). The origin of lymphoid stem cells studied in chick yold sac-embryo chimaeras. Nature 272: 353-354.

LAWSON, N.D., SCHEER, N., PHAM, V.N., KIM, C.H., CHITNIS, A.B., CAMPOSORTEGA, J.A. and WEINSTEIN, B.M. (2001). Notch signaling is required for arterial-venous differentiation during embryonic vascular development. Deve/opment 128: 3675-3683.

LAWSON, N.D., VOGEL, A.M. and WEINSTEIN, B.M. (2002). sonic hedgehog and vascular endothelial growth factor act upstream of the Notch pathway during arterial endothelial differentiation. Dev Ce//3: 127-136.

LEBESTKY, T., CHANG, T., HARTENSTEIN, V. and BANERJEE, U. (2000). Specification of Drosophila hematopoietic lineage by conserved transcription factors. Science 288: 146-9.

LEBESTKY, T., JUNG, S.H. and BANERJEE, U. (2003). A Serrate-expressing signaling center controls Drosophila hematopoiesis. Genes Dev17: 348-353.

LEE, C.Y., VOGELI, K.M., KIM, S.H., CHONG, S.W., JIANG, Y.J., STAINIER, D.Y. and JIN, S.W. (2009). Notch signaling functions as a cell-fate switch between the endothelial and hematopoietic lineages. Curr Bio/19: 1616-1622.

LESLIE, J.D., ARIZA-MCNAUGHTON, L., BERMANGE, A.L., MCADOW, R., JOHNSON, S.L. and LEWIS, J. (2007). Endothelial signalling by the Notch ligand Delta-like 4 restricts angiogenesis. Development 134: 839-844.

LEWIS, J. (1998). Notch signalling and the control of cell fate choices in vertebrates. Semin Cell Dev Biol9: 583-589.

LI, L., KRANTZ, I.D., DENG, Y., GENIN, A., BANTA, A.B., COLLINS, C.C., QI, M., TRASK, B.J., KUO, W.L., COCHRAN, J. et al. (1997). Alagille syndrome is caused by mutations in human Jagged1, which encodes a ligand for Notch1. Nat Genet 16: 243-251.

LOBOV, I.B., RENARD, R.A., PAPADOPOULOS, N., GALE, N.W., THURSTON, G., YANCOPOULOS, G.D. and WIEGAND, S.J. (2007). Delta-like ligand 4 (DII4) is induced by VEGF as a negative regulator of angiogenic sprouting. Proc Natl Acad Sci US A 104: 3219-3224.

MAILLARD, I., ADLER, S.H. and PEAR, W.S. (2003). Notch and the immune system. Immunity 19: 781-791.

MAILLARD, I., KOCH, U., DUMORTIER, A., SHESTOVA, O., XU, L., SAI, H., PROSS, S.E., ASTER, J.C., BHANDOOLA, A., RADTKE, F. et al. (2008). Canonical notch signaling is dispensable for the maintenance of adult hematopoietic stem cells. Cell Stem Cel/2: 356-366.

MANAIA, A., LEMARCHANDEL, V., KLAINE, M., MAX-AUDIT, I., ROMEO, P., DIETERLEN-LIEVRE, F. and GODIN, I. (2000). Lmo2 and GATA-3 associated expression in intraembryonic hemogenic sites. Development 127: 643-653. 
MANCINI, S.J., MANTEI, N., DUMORTIER, A., SUTER, U., MACDONALD, H.R. and RADTKE, F. (2005). Jagged1-dependent Notch signaling is dispensable for hematopoietic stem cell self-renewal and differentiation. Blood105: 2340-2342.

MANDAL, L., BANERJEE, U. and HARTENSTEIN, V. (2004). Evidence for a fruit fly hemangioblast and similarities between lymph-gland hematopoiesis in fruit fly and mammal aorta-gonadal-mesonephros mesoderm. Nat Genet36: 10191023.

MCCRIGHT, B., GAO, X., SHEN, L., LOZIER, J., LAN, Y., MAGUIRE, M., HERZLINGER, D., WEINMASTER, G., JIANG, R. and GRIDLEY, T. (2001). Defects in development of the kidney, heart and eye vasculature in mice homozygous for a hypomorphic Notch2 mutation. Development 128: 491-502.

MEDVINSKY, A. and DZIERZAK, E. (1996). Definitive hematopoiesis is autonomously initiated by the AGM region. Cel/86: 897-906.

METCALF, D., MOORE, A.S. and SHORTMAN, K. (1971). Adherence column and buoyant density separation of bone marrow stem cells and more differentiated cells. J Cell Physio/78: 441-450

MILNER, L.A. and BIGAS, A. (1999). Notch as a mediator of cell fate determination in hematopoiesis: evidence and speculation. Blood 93: 2431-2448.

MILNER, L.A., BIGAS, A., KOPAN, R., BRASHEM-STEIN, C., BERNSTEIN, I.D. and MARTIN, D.I. (1996). Inhibition of granulocytic differentiation by motch1. Proc Natl Acad Sci US A. 93: 13014-13019.

MILNER, L.A., KOPAN, R., MARTIN, D.I. and BERNSTEIN, I.D. (1994). A human homologue of the Drosophila developmental gene, Notch, is expressed in CD34+ hematopoietic precursors. Blood 83: 2057-2062.

MIYAMOTO, Y., MAITRA, A., GHOSH, B., ZECHNER, U., ARGANI, P., IACOBUZIODONAHUE, C.A., SRIURANPONG, V., ISO, T., MESZOELY, I.M., WOLFE, M.S. et al. (2003). Notch mediates TGF alpha-induced changes in epithelial differentiation during pancreatic tumorigenesis. Cancer Cel/3: 565-576.

MOHTASHAMI, M. and ZUNIGA-PFLUCKER, J.C. (2006). Three-dimensional architecture of the thymus is required to maintain delta-like expression necessary for inducing $T$ cell development. $J$ Immuno/176: 730-734.

MOLONEY, D.J., PANIN, V.M., JOHNSTON, S.H., CHEN, J., SHAO, L., WILSON, R., WANG, Y., STANLEY, P., IRVINE, K.D., HALTIWANGER, R.S. etal. (2000). Fringe is a glycosyltransferase that modifies Notch. Nature 406: 369-375.

MORGAN TH and CB, B. (1916). Sex-linked inheritance in Drosophila. Carnegie Inst. 237.

MULLER, A.M., MEDVINSKY, A., STROUBOULIS, J., GROSVELD, F. and DZIERZAK, E. (1994). Development of hematopoietic stem cell activity in the mouse embryo. Immunity. 1: 291-301.

NAKAGAWA, M., ICHIKAWA, M., KUMANO, K., GOYAMA, S., KAWAZU, M., ASAI, T., OGAWA, S., KUROKAWA, M. and CHIBA, S. (2006). AML1/Runx1 rescues Notch1-null mutation-induced deficiency of para-aortic splanchnopleural hematopoiesis. Blood 108: 3329-3334.

NICHOLS, J.T., MIYAMOTO, A., OLSEN, S.L., D'SOUZA, B., YAO, C. and WEINMASTER, G. (2007). DSL ligand endocytosis physically dissociates Notch1 heterodimers before activating proteolysis can occur. $J$ Cell Biol176: 445-458.

NOGUERA-TROISE, I., DALY, C., PAPADOPOULOS, N.J., COETZEE, S., BOLAND, P., GALE, N.W., LIN, H.C., YANCOPOULOS, G.D. and THURSTON, G. (2006). Blockade of DIl4 inhibits tumour growth by promoting non-productive angiogenesis. Nature 444: 1032-1037.

NORTH, T., GU, T.L., STACY, T., WANG, Q., HOWARD, L., BINDER, M., MARINPADILLA, M. and SPECK, N.A. (1999). Cbfa2 is required for the formation of intra-aortic hematopoietic clusters. Development 126: 2563-2575.

NORTH, T.E., DE BRUIJN, M.F., STACY, T., TALEBIAN, L., LIND, E., ROBIN, C., BINDER, M., DZIERZAK, E. and SPECK, N.A. (2002). Runx1 expression marks long-term repopulating hematopoietic stem cells in the midgestation mouse embryo. Immunity 16: 661-672.

NOTTINGHAM, W.T., JARRATT, A., BURGESS, M., SPECK, C.L., CHENG, J.F., PRABHAKAR, S., RUBIN, E.M., LI, P.S., SLOANE-STANLEY, J., KONG, A.S.J. et al. (2007). Runx1-mediated hematopoietic stem-cell emergence is controlled by a Gata/Ets/SCL-regulated enhancer. Blood110: 4188-4197.

OHISHI, K., KATAYAMA, N., SHIKU, H., VARNUM-FINNEY, B. and BERNSTEIN, I.D. (2003). Notch signalling in hematopoiesis. Semin Cel/Dev Bio/14: 143-150.

OHISHI, K., VARNUM-FINNEY, B., FLOWERS, D., ANASETTI, C., MYERSON, D. and BERNSTEIN, I.D. (2000). Monocytes express high amounts of Notch and undergo cytokine specific apoptosis following interaction with the Notch ligand Delta-1. Blood 95: 2847-2854.

OHTSUKA, T., ISHIBASHI, M., GRADWOHL, G., NAKANISHI, S., GUILLEMOT, F. and KAGEYAMA, R. (1999). Hes1 and Hes5 as notch effectors in mammalian neuronal differentiation. Embo J18: 2196-2207.

OKUDA, T., VAN DEURSEN, J., HIEBERT, S.W., GROSVELD, G. and DOWNING, J.R. (1996). AML1, the target of multiple chromosomal translocations in human leukemia, is essential for normal fetal liver hematopoiesis. Cel/84: 321-330.

OTTERSBACH, K. and DZIERZAK, E. (2005). The murine placenta contains hematopoietic stem cells within the vascular labyrinth region. Dev Ce//8: 377 387.

PALIS, J. and YODER, M.C. (2001). Yolk-sac hematopoiesis: the first blood cells of mouse and man. Exp Hemato/29: 927-936.

PALOMERO, T., LIM, W.K., ODOM, D.T., SULIS, M.L., REAL, P.J., MARGOLIN A., BARNES, K.C., O'NEIL, J., NEUBERG, D., WENG, A.P. et al. (2006). $\mathrm{NOTCH} 1$ directly regulates $\mathrm{C}-\mathrm{MYC}$ and activates a feed-forward-loop transcriptional network promoting leukemic cell growth. Proc Natl Acad Sci US A 103 $18261-18266$

PARKS, A.L., HUPPERT, S.S. and MUSKAVITCH, M.A. (1997). The dynamics of neurogenic signalling underlying bristle development in Drosophila Melanogaster. Mech Dev61-74.

PUI, J.C., ALLMAN, D., XU, L., DEROCCO, S., KARNELL, F.G., BAKKOUR, S., LEE, J.Y., KADESCH, T., HARDY, R.R., ASTER, J.C. et al. (1999). Notch1 expression in early lymphopoiesis influences $B$ versus $T$ lineage determination. Immunity 11: 299-308

RADTKE, F., WILSON, A., STARK, G., BAUER, M., VAN MEERWIJK, J., MACDONALD, H.R. and AGUET, M. (1999). Deficient T cell fate specification in mice with an induced inactivation of Notch1. Immunity 10: 547-558.

RANGARAJAN, A., TALORA, C., OKUYAMA, R., NICOLAS, M., MAMMUCARI, C., OH, H., ASTER, J.C., KRISHNA, S., METZGER, D., CHAMBON, P. et al. (2001). Notch signaling is a direct determinant of keratinocyte growth arrest and entry into differentiation. Embo J20: 3427-3436.

REBAY, I., FLEMING, R.J., FEHON, R.G., CHERBAS, L., CHERBAS, P. and ARTAVANIS-TSAKONAS, S. (1991). Specific EGF repeats of Notch mediate interactions with Delta and Serrate: implications for Notch as a multifunctional receptor. Cel/67: 687-699.

RIDGWAY, J., ZHANG, G., WU, Y., STAWICKI, S., LIANG, W.C., CHANTHERY, Y., KOWALSKI, J., WATTS, R.J., CALLAHAN, C., KASMAN, I. et al. (2006). Inhibition of DII4 signalling inhibits tumour growth by deregulating angiogenesis. Nature 444: 1083-1087.

RIZKI, M.T. and RIZKI, R.M. (1959). Functional significance of the crystal cells in the larva of Drosophila Melanogaster. J Biophys Biochem Cyto/5: 235-240.

ROBB, L., LYONS, I., LI, R., HARTLEY, L., KONTGEN, F., HARVEY, R.P., METCALF, D. and BEGLEY, C.G. (1995). Absence of yolk sac hematopoiesis from mice with a targeted disruption of the scl gene. Proc Natl Acad Sci USA 92: 7075-7079.

ROBERT-MORENO, A., ESPINOSA, L., DE LA POMPA, J.L. and BIGAS, A. (2005). RBPjkappa-dependent Notch function regulates Gata2 and is essential for the formation of intra-embryonic hematopoietic cells. Development 132: 1117-1126.

ROBERT-MORENO, A., ESPINOSA, L., SANCHEZ, M.J., DE LA POMPA, J.L. and BIGAS, A. (2007). The notch pathway positively regulates programmed cell death during erythroid differentiation. Leukemia 21: 1496-1503.

ROBERT-MORENO, A., GUIU, J., RUIZ-HERGUIDO, C., LOPEZ, M.E., INGLESESTEVE, J., RIERA, L., TIPPING, A., ENVER, T., DZIERZAK, E., GRIDLEY, T. et al. (2008). Impaired embryonic haematopoiesis yet normal arterial development in the absence of the Notch ligand Jagged1. Embo J27: 1886-1895.

ROBEY, E., CHANG, D., ITANO, A., CADO, D., ALEXANDER, H., LANS, D., WEINMASTER, G. and SALMON, P. (1996). An activated form of Notch influences the choice between CD4 and CD8 T cell lineages. Cel/87: 483-492.

RODILLA, V., VILLANUEVA, A., OBRADOR-HEVIA, A., ROBERT-MORENO, A., FERNANDEZ-MAJADA, V., GRILLI, A., LOPEZ-BIGAS, N., BELLORA, N., ALBA, M.M., TORRES, F. etal. (2009). Jagged1 is the pathological link between Wnt and Notch pathways in colorectal cancer. Proc Natl Acad Sci U S A 106: 6315-6320.

SABIN, F.R. (2002). Preliminary note on the differentiation of angioblasts and the 
method by which they produce blood-vessels, blood-plasma and red blood-cells as seen in the living chick. 1917. J Hematother Stem Cell Res 11: 5-7.

SCEHNET, J.S., JIANG, W., KUMAR, S.R., KRASNOPEROV, V., TRINDADE, A., BENEDITO, R., DJOKOVIC, D., BORGES, C., LEY, E.J., DUARTE, A. et al. (2007). Inhibition of Dll4-mediated signaling induces proliferation of immature vessels and results in poor tissue perfusion. Blood 109: 4753-4760.

SHALABY, F., HO, J., STANFORD, W.L., FISCHER, K.D., SCHUH, A.C., SCHWARTZ, L., BERNSTEIN, A. and ROSSANT, J. (1997). A requirement for Flk1 in primitive and definitive hematopoiesis and vasculogenesis. Ce//89: 981990.

SHALABY, F., ROSSANT, J., YAMAGUCHI, T.P., GERTSENSTEIN, M., WU, X.F., BREITMAN, M.L. and SCHUH, A.C. (1995). Failure of blood-island formation and vasculogenesis in Flk-1-deficient mice. Nature 376: 62-66.

SHIMIZU, K., CHIBA, S., HOSOYA, N., KUMANO, K., SAITO, T., KUROKAWA, M., KANDA, Y., HAMADA, Y. and HIRAI, H. (2000a). Binding of delta1, jagged1, and jagged2 to notch2 rapidly induces cleavage, nuclear translocation, and hyperphosphorylation of notch2. Mol Cel/ Bio/20: 6913-6922.

SHIMIZU, K., CHIBA, S., SAITO, T., KUMANO, K. and HIRAI, H. (2000b). Physical interaction of Delta1, Jagged1, and Jagged2 with Notch1 and Notch3 receptors. Biochem Biophys Res Commun 276: 385-389.

SIEKMANN, A.F. and LAWSON, N.D. (2007). Notch signalling limits angiogenic cell behaviour in developing zebrafish arteries. Nature 445: 781-784.

SILVER, L. and PALIS, J. (1997). Initiation of murine embryonic erythropoiesis: a spatial analysis. Blood 89: 1154-1164.

STIER, S., CHENG, T., DOMBKOWSKI, D., CARLESSO, N. and SCADDEN, D.T. (2002). Notch1 activation increases hematopoietic stem cell self-renewaln in vivo and favors lymphoid over myeloid lineage outcome. Blood99: 2369-2378.

SUCHTING, S., FREITAS, C., LE NOBLE, F., BENEDITO, R., BREANT, C., DUARTE, A. and EICHMANN, A. (2007). The Notch ligand Delta-like 4 negatively regulates endothelial tip cell formation and vessel branching. Proc Nat/ Acad Sci U S A 104: 3225-3230.

TANIGAKI, K., TSUJI, M., YAMAMOTO, N., HAN, H., TSUKADA, J., INOUE, H., KUBO, M. and HONJO, T. (2004). Regulation of alphabeta/gammadelta T cell lineage commitment and peripheral T cell responses by Notch/RBP-J signaling. Immunity 20: 611-622.

TAVIAN, M., COULOMBEL, L., LUTON, D., CLEMENTE, H.S., DIETERLENLIEVRE, F. and PEAULT, B. (1996). Aorta-associated CD34+ hematopoietic cells in the early human embryo. Blood 87: 67-72.

THOMPSON, B.J., BUONAMICI, S., SULIS, M.L., PALOMERO, T., VILIMAS, T., BASSO, G., FERRANDO, A. and AIFANTIS, I. (2007). The SCFFBW7 ubiquitin ligase complex as a tumor suppressor in T cell leukemia. J Exp Med204: 18251835

THOMPSON, M.A., RANSOM, D.G., PRATT, S.J., MACLENNAN, H., KIERAN, M.W., DETRICH, H.W., 3RD, VAIL, B., HUBER, T.L., PAW, B., BROWNLIE, A.J. et al. (1998). The cloche and spadetail genes differentially affect hematopoiesis and vasculogenesis. Dev Bio/ 197: 248-269.

timmerman, L.A., GRego-Bessa, J., RAYA, A., Bertran, E., PEREZPOMARES, J.M., DIEZ, J., ARANDA, S., PALOMO, S., MCCORMICK, F., IZPISUA-BELMONTE, J.C. et al. (2004). Notch promotes epithelial-mesenchymal transition during cardiac development and oncogenic transformation. Genes Dev 18: 99-115.

URNESS, L.D., SORENSEN, L.K. and LI, D.Y. (2000). Arteriovenous malformations in mice lacking activin receptor-like kinase-1. Nat Genet 26: 328-331.

VAN ES, J.H., VAN GIJN, M.E., RICCIO, O., VAN DEN BORN, M., VOOIJS, M., BEGTHEL, H., COZIJNSEN, M., ROBINE, S., WINTON, D.J., RADTKE, F. etal. (2005). Notch/gamma-secretase inhibition turns proliferative cells in intestinal crypts and adenomas into goblet cells. Nature 435: 959-963.

VARNUM-FINNEY, B., BRASHEM-STEIN, C. and BERNSTEIN, I.D. (2003). Combined effects of Notch signaling and cytokines induce a multiple log increase in precursors with lymphoid and myeloid reconstituting ability. Blood 101: 17841789.

VARNUM-FINNEY, B., XU, L., BRASHEM-STEIN, C., NOURIGAT, C., FLOWERS, D., BAKKOUR, S., PEAR, W.S. and BERNSTEIN, I.D. (2000). Pluripotent, cytokine-dependent, hematopoietic stem cells are immortalized by constitutive Notch1 signaling. Nat Med6: 1278-1281.

VERCAUTEREN, S.M. and SUTHERLAND, H.J. (2004). Constitutively active
Notch4 promotes early human hematopoietic progenitor cell maintenance while inhibiting differentiation and causes lymphoid abnormalities in vivo. Blood104: 2315-2322.

VILIMAS, T., MASCARENHAS, J., PALOMERO, T., MANDAL, M., BUONAMICI, S., MENG, F., THOMPSON, B., SPAULDING, C., MACAROUN, S., ALEGRE, M.L. et al. (2007). Targeting the NF-kappaB signaling pathway in Notch1induced T-cell leukemia. Nat Med13: 70-77.

WALKER, L., CARLSON, A., TAN-PERTEL, H.T., WEINMASTER, G. and GASSON, J. (2001). The notch receptor and its ligands are selectively expressed during hematopoietic development in the mouse. Stem Cel/s 19: 543-552.

WANG, L., LI, L., SHOJAEI, F., LEVAC, K., CERDAN, C., MENENDEZ, P., MARTIN, T., ROULEAU, A. and BHATIA, M. (2004). Endothelial and hematopoietic cell fate of human embryonic stem cells originates from primitive endothelium with hemangioblastic properties. Immunity 21: 31-41.

WASHBURN, T., SCHWEIGHOFFER, E., GRIDLEY, T., CHANG, D., FOWLKES, B.J., CADO, D. and ROBEY, E. (1997). Notch activity influences the alphabeta versus gammadelta T cell lineage decision. Cel/88: 833-843.

WENG, A.P., FERRANDO, A.A., LEE, W., MORRIS, J.P.T., SILVERMAN, L.B., SANCHEZ-IRIZARRY, C., BLACKLOW, S.C., LOOK, A.T. and ASTER, J.C. (2004). Activating mutations of NOTCH1 in human T cell acute lymphoblastic leukemia. Science 306: 269-271.

WENG, A.P., MILLHOLLAND, J.M., YASHIRO-OHTANI, Y., ARCANGELI, M.L., LAU, A., WAI, C., DEL BIANCO, C., RODRIGUEZ, C.G., SAI, H., TOBIAS, J. et al. (2006). c-Myc is an important direct target of Notch1 in T-cell acute lymphoblastic leukemia/lymphoma. Genes Dev20: 2096-2109.

XUE, Y., GAO, X., LINDSELL, C.E., NORTON, C.R., CHANG, B., HICKS, C., GENDRON-MAGUIRE, M., RAND, E.B., WEINMASTER, G. and GRIDLEY, T. (1999). Embryonic lethality and vascular defects in mice lacking the Notch ligand Jagged1. Hum Mol Genet 8: 723-730.

YODER, M.C. and HIATT, K. (1997). Engraftment of embryonic hematopoietic cells in conditioned newborn recipients. Blood89: 2176-2183.

YODER, M.C., HIATT, K., DUTT, P., MUKHERJEE, P., BODINE, D.M. and ORLIC, D. (1997a). Characterization of definitive lymphohematopoietic stem cells in the day 9 murine yolk sac. Immunity 7: 335-344.

YODER, M.C., HIATT, K. and MUKHERJEE, P. (1997b). In vivo repopulating hematopoietic stem cells are present in the murine yolk sac at day 9.0 postcoitus. Proc Nat/ Acad Sci U S A 94: 6776-6780.

YOON, M.J., KOO, B.K., SONG, R., JEONG, H.W., SHIN, J., KIM, Y.W., KONG Y.Y. and SUH, P.G. (2008). Mind bomb-1 is essential for intraembryonic hematopoiesis in the aortic endothelium and the subaortic patches. Mol Cel/ Biol 28: 4794-4804.

YOU, L.R., LIN, F.J., LEE, C.T., DEMAYO, F.J., TSAI, M.J. and TSAI, S.Y. (2005). Suppression of Notch signalling by the COUP-TFII transcription factor regulates vein identity. Nature 435: 98-104.

YOUNG, P.E., BAUMHUETER, S. and LASKY, L.A. (1995). The sialomucin CD34 is expressed on hematopoietic cells and blood vessels during murine development. Blood 85: 96-105.

ZEIGLER, B.M., SUGIYAMA, D., CHEN, M., GUO, Y., DOWNS, K.M. and SPECK N.A. (2006). The allantois and chorion, when isolated before circulation or chorio-allantoic fusion, have hematopoietic potential. Development 133: 41834192.

ZHANG, Z., NADEAU, P., SONG, W., DONOVIEL, D., YUAN, M., BERNSTEIN, A and YANKNER, B.A. (2000). Presenilins are required for gamma-secretase cleavage of beta-APP and transmembrane cleavage of Notch-1. Nat Cell Biol 2: 463-465.

ZHONG, T.P., CHILDS, S., LEU, J.P. and FISHMAN, M.C. (2001). Gridlock signalling pathway fashions the first embryonic artery. Nature 414: 216-220.

ZHONG, T.P., ROSENBERG, M., MOHIDEEN, M.A., WEINSTEIN, B. and FISHMAN, M.C. (2000). gridlock, an HLH gene required for assembly of the aorta in zebrafish. Science 287: 1820-1824.

ZHOU, L., LI, L.W., YAN, Q., PETRYNIAK, B., MAN, Y., SU, C., SHIM, J., CHERVIN, S. and LOWE, J.B. (2008). Notch-dependent control of myelopoiesis is regulated by fucosylation. Blood 112: 308-319.

ZOVEIN, A.C., HOFMANN, J.J., LYNCH, M., FRENCH, W.J., TURLO, K.A., YANG Y., BECKER, M.S., ZANETTA, L., DEJANA, E., GASSON, J.C. et al. (2008). Fate tracing reveals the endothelial origin of hematopoietic stem cells. Cell Stem Cel/3: 625-636. 


\section{Further Related Reading, published previously in the Int. J. Dev. Biol.}

See our recent Special Issue Placenta edited by Joan S. Hunt and Kent L. Thornburg at: http://www.ijdb.ehu.es/web/contents.php?vol=54\&issue=2-3

Dynamic expression of Endoglin, a TGF-beta co-receptor, during pre-circulation vascular development in chick Cantas Alev, Brendan A.S. McIntyre, Kanako Ota and Guojun Sheng

Int. J. Dev. Biol. (2010) 54: 737-742 (doi: 10.1387/ijdb.092962ca)

Epiblast-derived stem cells in embryonic and adult tissues

Maria P. De-Miguel, Francisco Arnalich-Montiel, Pilar Lopez-Iglesias, Alejandro Blazquez-Martinez and Manuel Nistal Int. J. Dev. Biol. (2009) 53: 1529-1540

«Notch-Off»: a perspective on the termination of Notch signalling

Rita Fior and Domingos Henrique

Int. J. Dev. Biol. (2009) 53: 1379-1384

Activated Notch1 is a stronger astrocytic stimulus than leukemia inhibitory factor for rat neural stem cells Nidia S. Rodríguez-Rivera, Anayansi Molina-Hernández, Erika Sánchez-Cruz, Diana Escalante-Alcalde and Iván Velasco Int. J. Dev. Biol. (2009) 53: 947-953

Cell cycle control of Notch signaling and the functional regionalization of the neuroepithelium during vertebrate neurogenesis

Maria Jesús Latasa, Elsa Cisneros and Jose María Frade

Int. J. Dev. Biol. (2009) 53: 895-908

A novel role of the glial fate determinant glial cells missing in hematopoiesis Cécile Jacques, Laurent Soustelle, István Nagy, Céline Diebold and Angela Giangrande Int. J. Dev. Biol. (2009) 53: 1013-1022

Developmentally regulated expression of hemoglobin subunits in avascular tissues Fiona C. Mansergh, Susan M. Hunter, Jenny C. Geatrell, Miguel Jarrin, Kate Powell, Martin J. Evans and Michael A. Wride

Int. J. Dev. Biol. (2008) 52: 873-886

Embryonic development of the proepicardium and coronary vessels Anna Ratajska, Elzbieta Czarnowska and Bogdan Ciszek Int. J. Dev. Biol. (2008) 52: 229-236

Interleukin-2 induces the proliferation of mouse primordial germ cells in vitro Cristina Eguizabal, Maria D. Boyano, Alejandro Díez-Torre, Ricardo Andrade, Noelia Andollo, Massimo De Felici and Juan Aréchaga

Int. J. Dev. Biol. (2007) 51: 731-738

Tracing the hemangioblast during embryogenesis: developmental relationships between endothelial and hematopoietic cells

Thierry Jaffredo, Karine Bollerot, Daisuke Sugiyama, Rodolphe Gautier and Cécile Drevon

Int. J. Dev. Biol. (2005) 49: 269-277

Of birds and mice: hematopoietic stem cell development Isabelle Godin and Ana Cumano

Int. J. Dev. Biol. (2005) 49: 251-257

Embryonic development of the human hematopoietic system

Manuela Tavian and Bruno Péault

Int. J. Dev. Biol. (2005) 49: 243-250

Notch in vertebrates - molecular aspects of the signal

Ken-Ichi Katsube and Kei Sakamoto

Int. J. Dev. Biol. (2005) 49: 369-374

Multilineage hematopoietic progenitor activity generated autonomously in the mouse yolk sac: analysis using angiogenesis-defective embryos Christine Rampon and Philippe Huber Int. J. Dev. Biol. (2003) 47: 273-280

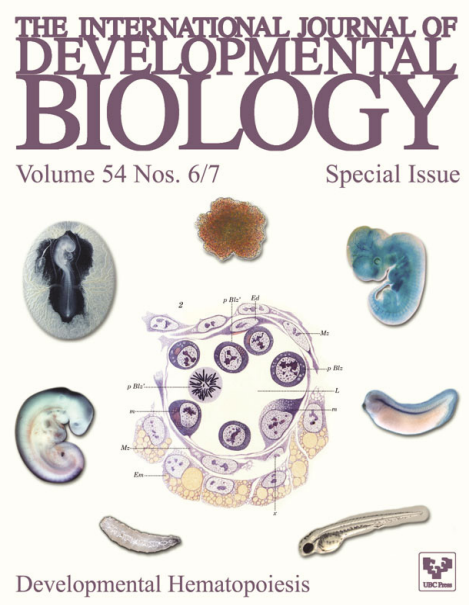

5 yr ISI Impact Factor $(2009)=3.253$

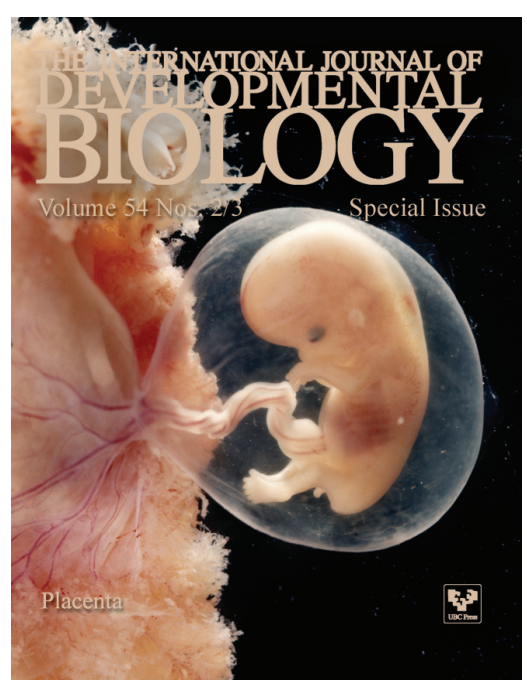

